IZA DP No. 5580

Cigarette Taxes and the Social Market

Benjamin Hansen

Joseph J. Sabia

Daniel I. Rees

March 2011 


\title{
Cigarette Taxes and the Social Market
}

\author{
Benjamin Hansen
}

University of Oregon

Joseph J. Sabia

U.S. Military Academy

Daniel I. Rees

University of Colorado Denver

and IZA

\section{Discussion Paper No. 5580 \\ March 2011}

IZA

P.O. Box 7240

53072 Bonn

Germany

Phone: +49-228-3894-0

Fax: +49-228-3894-180

E-mail: iza@iza.org

Any opinions expressed here are those of the author(s) and not those of IZA. Research published in this series may include views on policy, but the institute itself takes no institutional policy positions.

The Institute for the Study of Labor (IZA) in Bonn is a local and virtual international research center and a place of communication between science, politics and business. IZA is an independent nonprofit organization supported by Deutsche Post Foundation. The center is associated with the University of Bonn and offers a stimulating research environment through its international network, workshops and conferences, data service, project support, research visits and doctoral program. IZA engages in (i) original and internationally competitive research in all fields of labor economics, (ii) development of policy concepts, and (iii) dissemination of research results and concepts to the interested public.

IZA Discussion Papers often represent preliminary work and are circulated to encourage discussion. Citation of such a paper should account for its provisional character. A revised version may be available directly from the author. 


\section{ABSTRACT}

\section{Cigarette Taxes and the Social Market ${ }^{*}$}

Previous researchers have argued that the social market for cigarettes insulates its participants from policies designed to curb youth smoking. Using state Youth Risk Behavior Survey data, we examine whether recent changes in state cigarette taxes affected how young smokers obtained their cigarettes. Our estimates suggest that tax increases reduce youth smoking participation primarily through their effect on third-party purchase, although there is evidence that they are negatively related to borrowing among younger teenagers and negatively related to direct purchase among older teenagers.

\section{NON-TECHNICAL SUMMARY}

Most teenage smokers in the United States participate in what is called the social market for cigarettes. In fact, 70 to 90 percent of teenage smokers report borrowing, stealing, or buying cigarettes from friends, family or strangers as opposed to buying their cigarettes directly from a commercial establishment. Despite the importance of the social market, we know very little about its interaction with policies designed to curb youth smoking. Analyzing data on U.S. high school students for the period 1995-2009, we find evidence that state cigarette taxes reduce youth smoking participation primarily through their effect on third-party purchases, an important component of the social market. In addition, we find that taxes are negatively related to the probability that younger teenagers borrow cigarettes. These results do not support the claim made by previous researchers that the social market should insulate young smokers against anti-smoking policies by serving as an alternative source of cigarettes.

JEL Classification: $\quad 110, I 12$

Keywords: $\quad$ youth smoking, cigarette taxes

Corresponding author:

Benjamin Hansen

Department of Economics

1285 University of Oregon

Eugene, OR 9740

USA

E-mail: bchansen@uoregon.edu

\footnotetext{
* The views expressed herein are those of the authors and do not reflect the position of the United States Military Academy, the Department of the Army, or the Department of Defense.
} 


\section{INTRODUCTION}

Most teenage smokers participate in what is called the social market for cigarettes. In fact, 70 to 90 percent of teenage smokers report borrowing, stealing, or buying cigarettes from friends, family or strangers as opposed to buying their cigarettes directly from a commercial establishment (Croghan et al. 2003; Forster et al. 2003).

Despite the importance of the social market, we know very little about its interaction with policies designed to curb youth smoking. Previous researchers have argued that the social market should insulate young smokers against such policies by serving as an alternative source of cigarettes (Friend et al. 2001; Ribisl 2003). However, there are several reasons to view this argument with a certain degree of skepticism. For instance, if commercial establishments are required to diligently check IDs, then the supply of cigarettes to the social market could decrease.

Our analysis uses state YRBS data at the individual level for the period 1995 though 2009 to estimate the effect of state cigarette taxes, an important policy tool, on the social market. Because we have more observations per state-year than were available to previous researchers, and because cigarette tax increases were substantially larger in the 2000s than during the mid-to-late 1990s (Carpenter and Cook 2008), we are able to account for unobserved heterogeneity by including state fixed effects and state-specific time trends. In addition, we are able to distinguish between borrowing, direct purchase, third-party purchase, and obtaining cigarettes through other sources including vending machines and stealing.

We begin our analysis by confirming that there was a negative relationship between state cigarette taxes and youth smoking during the period under study. Next, we turn to 
estimating the effect of taxes on how youth usually obtained their cigarettes. Multinomial logit estimates suggest that taxes reduce youth smoking participation primarily through their effect on third-party purchases, although they are negatively related to the probability that younger teenagers (14- and 15-year-olds) borrow cigarettes, and negatively related to the probability that older teenagers (16- through 18-year-olds) directly purchase cigarettes from a commercial establishment. When we condition on frequent or everyday smoking, there is strong evidence that tax increases push teenage smokers away from third-party purchase and toward obtaining their cigarettes from other sources.

\section{BACKGROUND}

Until recently, researchers believed that teenage smoking participation was highly sensitive to changes in the price of cigarettes. In fact, the "conventional wisdom" held that teenagers were more sensitive to changes in the price of cigarettes than adults (Carpenter and Cook 2008). ${ }^{1}$

The results of recent studies by DeCicca, Kenkel and Mathios (2002) and Carpenter and Cook (2008) have cast doubt on the conventional wisdom. Using data from the National Educational Longitudinal Study, DeCicca, Kenkel and Mathios (2002) found that difficultto-measure factors at the state level could explain nearly the entire relationship between youth smoking participation and cigarette taxes. Using data from state YRBS surveys, Carpenter and Cook (2008) found that a 10 percent increase in the price of cigarettes was

\footnotetext{
${ }^{1}$ There is evidence that state cigarette tax increases are passed on to consumers almost dollar for dollar. For instance, Barnett, Keeler and $\mathrm{Hu}$ (1995) estimated that a one-dollar increase in the state cigarette tax leads to a 90 cent increase in the price paid by consumers. Using data from The Tax Burden on Tobacco: Historical Compilation (Orzechowsku and Walker 2009) for the period 1995 through 2009, we find that a one-dollar increase in the per-pack cigarette tax is associated with an increase in the per-pack retail price of 97 cents. See also Hanson and Sullivan (2009) and DeCicca, Kenkel and Liu (2010).
} 
associated with only a $2.5 \%$ decrease in youth smoking participation - an estimate that suggests teenagers are considerably less sensitive to changes in the price of cigarettes than adults (Evans, Ringel and Stech 1999; Franz 2008).

Most teenage smokers depend, at least in part, on the social market to obtain cigarettes. According to previous studies such as Croghan et al. (2003) and Forster et al. (2003), 70 to 90 percent of teenage smokers report borrowing, buying, or stealing cigarettes. Could the importance of the social market explain the results of DeCicca, Kenkel and Mathios (2002) and Carpenter and Cook (2008)? In other words, is it possible that the social market insulates young smokers by serving as an alternative source of cigarettes when the price charged by commercial establishments goes up? A number of authors have argued that the social market for cigarettes dampens the effectiveness of anti-smoking policies (Friend et al. 2001; Ribisl 2003). For instance, according to Ribisl (2003, p. 115),

When there are "crackdowns" on sales to minors at stores, many youth simply switch their usual source of cigarettes. Social sources have simply filled the void. ${ }^{2}$

If social sources serve as a substitute to direct purchase from commercial establishments, then increases in the cigarette tax should encourage participation in the social market. On the other hand, if tax increases make obtaining cigarettes through the social market more difficult, then we should observe the opposite relationship.

\footnotetext{
${ }^{2}$ In a similar vein, Friend et al. (2001, p. 507) wrote:
}

One of the reasons that retail-based policies have failed to significantly reduce youth smoking rates is attributable in part to youths substituting social or non-retail sources of cigarettes for retail supply. The widespread availability of cigarettes through social sources such as borrowing, stealing, or buying cigarettes from parents, older siblings, and peers, and requesting older strangers to purchase them highlights the difficulty of eliminating all supplies of youth cigarettes. Strategies should be implemented that are developed specifically to reduce access from social sources. 
There are, in fact, several reasons to expect the relative cost of obtaining cigarettes through the social market to be positively related to taxes: parents, siblings and friends may quit smoking if it becomes too expensive, increasing the relative cost of participation in the social market through reducing opportunities to steal and borrow; third-party sellers may charge more in response to new taxes ${ }^{3}$; or smokers may become increasingly reluctant to lend cigarettes as the price charged by commercial establishments goes up, leaving smokers without sufficient social capital (in particular, younger smokers) unable to borrow.

In an often-cited article, Coleman (1988, p. S98) defined social capital as constituting a "particular kind of resource available to an actor... making possible the achievement of certain ends that in its absence would not be possible." He went on to explain that social capital

comes about through changes in the relations among persons that facilitate action. If physical capital is wholly tangible, being embodied in observable material form, and human capital is less tangible, being embodied in the skills and knowledge acquired by an individual, social capital is less tangible yet, for it exists in the relations among persons (Coleman 1988, pp. S100-S101). ${ }^{4}$

Below, we explore the effect of taxes on how youth obtain their cigarettes, paying special attention to the roles of age and intensity of tobacco use. We hypothesize that, because they have had less time to accrue social capital, younger smokers may be pushed out of the social market when cigarette prices rise. Similarly, if the act of smoking itself increases

\footnotetext{
${ }^{3}$ If, for instance, third-party sellers impose a markup over the commercial price, but can compete with commercial establishments because they do not check IDs, then a new tax will result in an increase in the relative cost of third-party purchase.

${ }^{4}$ There are, of course, alternative definitions of social capital. For instance, Bourdieu (1986, p. 248) defined social capital as the "aggregate of the actual or potential resources which are linked to possession of a durable network of more or less institutionalized relationships of mutual acquaintance and recognition..."; and Woolcock and Narayan (2000, p. 226) defined social capital as referring to the "norms and networks that enable people to act collectively." See Woolcock and Narayan (2000) for more information on social capital and its applications.
} 
social status or helps to promote friendships with other smokers, then we would expect experimental and light smokers to have less social capital on which to draw than frequent smokers and therefore be more susceptible to being pushed out of the social market. ${ }^{5}$

To our knowledge, only one previous study has explored the relationship between cigarette taxes and the social market. Using data from the national Youth Risk Behavior Survey (YRBS), Katzman, Markowitz and McGeary (2007) found that state excise taxes on cigarettes taxes have little impact on borrowing or "bumming." However, these authors examined data from only four national YRBS surveys (1995, 1997, 1999 and 2001) conducted during a period when there was limited within-state variation in cigarette taxes. As a consequence, they were forced to rely on cross-state variation for identification, and their estimates, although intriguing, could reflect difficult-to-measure factors at the state level such as anti-smoking sentiment. ${ }^{6}$

\section{DATA AND MEASURES}

\footnotetext{
${ }^{5}$ We are not the first researchers to hypothesize that there is a link between social capital and smoking behavior. Lindström (2003) found that daily smoking was negatively associated with social participation, whereas intermittent smoking was positively associated with social participation; and Brown et al. (2006, p. 1159 ) found that the "proportion of community social capital attributable to religious groups" was negatively related to smoking intensity.

Neither the state nor national YRBS asks about the smoking behavior of friends or acquaintances. In an effort to explore the extent to which age and smoking intensity might impact access to the social market, we turned to data from Wave I of the National Longitudinal Study of Adolescent Health (Add Health), a schoolbased nationally representative survey of 7th-12th graders conducted in 1995. Add Health respondents were asked, "[o]f your 3 best friends, how many smoke at least 1 cigarette a day?"

Not surprisingly, we found that 14- and 15-year-olds reported fewer friends who smoked than 16-, 17-, and 18-year-olds. In addition, we found that 14- and 15-year-old smokers reported fewer friends who smoked than 16-, 17-, and 18-year-old smokers. Finally, we found that, conditional on age, both smoking intensity and years since first cigarette were positively related to how many friends the respondent had who smoked. These results are presented in Appendix Tables 1A and 1B. Although far from definitive, we view them as consistent with the notion that older teenagers and more frequent/dedicated smokers should have easier access to the social market for cigarettes.

${ }^{6}$ Using data on young adults drawn from the National Education Longitudinal Study, DeCicca, Kenkel and Mathios (2008) found that anti-smoking sentiment can explain much of the cross-state relationship between taxes and youth smoking participation.
} 
The current study relies on state Youth Risk Behavior Survey (YRBS) data at the individual level for the period 1995-2009. The state versions of the YRBS are school-based, and contain many of the same questions as the national YRBS. They are coordinated by the Centers for Disease Control, and are typically administered to high school students every other year.

A number of previous studies have used national YRBS data to examine the relationship between cigarette taxes and youth smoking participation (Gruber and Zinman 2001; Bishai, Mercer and Athena Tapales 2005; Carpenter and Cook 2008). To our knowledge, the only previous study in this area to use state YRBS data is by Carpenter and Cook (2008). These authors, however, did not have access to information at the individual level from the state surveys.

The principal advantage to using state, as opposed to national, YRBS data is that we often have 1000 s of observations per state-year. ${ }^{7}$ Estimating a non-linear model with state fixed effects requires more observations per state-year than linear models in which the state fixed effects are eliminated through mean differencing. States typically provide hundreds, and occasionally only dozens, of observations to the national YRBS in any given year, posing an obstacle to obtaining consistent parameter estimates from a non-linear model such as a multinomial logit. For instance, 18 of 25 states contributed fewer than 1,000

\footnotetext{
${ }^{7}$ For more information on the state YRBS data collection effort see: http://www.cdc.gov/HealthyYouth/yrbs/index.htm. Appendix Table 2 shows which states collected and released data to the Centers for Disease Control and Prevention (CDC) on how young smokers usually obtained their cigarettes by year. It also shows sample size by state and year. Importantly, no state contributed fewer than 1,000 observations in any given year. Our focus is restricted to the 24 states that: conducted a YRBS, gave the CDC permission to distribute the results, asked questions with regard to how respondents usually obtained their cigarettes, and provided at least two years of individual-level data to the CDC. Among these states, the mean cigarette tax increase was 34 cents (in 2005 dollars) during the period 1995- 2001. In comparison, the mean cigarette tax increase was 59 cents during the period 2002-2009. Appendix Table 3 shows nominal cigarette taxes by state and year.
} 
observations to the 2009 national YRBS; 9 contributed fewer than 300 observations; and 2 contributed 100 or fewer observations. In their seminal work, Neyman and Scott (1948) showed that estimating non-linear models with limited data can result in problems with incidental parameters, raising both theoretical and computational concerns. ${ }^{8}$

The principal disadvantage to using state YRBS data is that they are not designed to be nationally representative. However, comparing the information contained in state surveys with that from other sources can help gauge the severity of any potential bias. Table 1A shows the prevalence of smoking among state YRBS respondents for the period 1995-2009. In addition, it shows the prevalence of frequent smoking (defined as having smoked on 20 of the past 30 days) and everyday smoking. ${ }^{9} \quad$ Twenty-five percent of the respondents in our sample smoked at least once in the past 30 days; 12 percent were frequent smokers; and 9 percent were everyday smokers. ${ }^{10}$ Despite the fact that the state YRBS data are not designed to be nationally representative, these figures are quite similar to those obtained using weighted data from the national YRBS for the same period (Table 1B).

In a further effort to explore this issue, we examine smoking participation trends for 10th and 12th graders based on state YRBS data, weighted national YRBS data, and weighted data from Monitoring the Future (MTF), a school-based, nationally representative survey (Figures 1 and 2). ${ }^{11}$ Although smoking participation rates in the state and national

\footnotetext{
${ }^{8}$ Lancaster (2000) provides an excellent overview of this issue. See also Green (2004), who showed via simulation that the bias resulting from incidental parameters is reduced considerably as group size increases. Green's Monte-Carlo findings for discrete choice models - including logits and ordered logits - highlight the benefits to using data from the state, as opposed to the national, YRBS.

${ }^{9}$ This is the same definition of frequent smoking as was used by Carpenter and Cook (2008).

${ }^{10}$ These figures were based on unweighted answers to the question, "[d] uring the past 30 days, on how many days did you smoke cigarettes?"

${ }^{11}$ We focus on 10 th and 12 th graders because the MTF interviews 8th, 10th, and 12th graders, while the state and national YRBS data contain information on 9th, 10th, 11th, and 12th graders.
} 
YRBS data are 3 to 8 percentage points higher than those in MTF, the trends in participation are similar across all three surveys, suggesting that they captured the same broad changes in preferences and responses to policy. ${ }^{12}$

In addition to asking how many cigarettes were consumed in the past 30 days, state and national YRBS respondents were asked about how they obtained their cigarettes. Specifically, they were asked: "[d] uring the past 30 days, how did you usually get your own cigarettes?" The possible answers were:

(1) I did not smoke cigarettes during the past 30 days.

(2) I bought them in a store such as a convenience store, supermarket, discount store, or gas station.

(3) I gave someone else money to buy them for me.

(4) I borrowed (or bummed) them from someone else.

(5) A person 18 years old or older gave them to me.

(6) I bought them from a vending machine.

(7) I took them from a store or family member.

(8) I got them some other way.

By combining responses (4) and (5), and combining responses (6), (7) and (8), we created four outcomes: Direct Purchase, Third-Party Purchase, Borrowed, and Vending Machine, Stealing or Other. ${ }^{13}$

Figure 3 presents trends in these outcomes for state YRBS respondents who smoked. It is clear from Figure 3 that the social market has become more important since the mid1990s. In 1995, more than 40 percent of state YRBS respondents who smoked obtained their cigarettes through direct purchase; by 2009, only 25 percent obtained their cigarettes through direct purchase. Over the same period, third-party purchase, borrowing and other methods of obtaining cigarettes including stealing and vending machines increased in relative

\footnotetext{
${ }^{12}$ Although the national YRBS has been an important source of data for researchers in this area, because neither MTF nor the National Survey on Drug Use and Health (NSDUH) typically provide state-identifiers, they have been of less value to researchers interested in cigarette taxes and the smoking behavior of youths. Our attempts at obtaining individual-level MTF and NSDUH data with state identifiers were politely rebuffed.

${ }^{13}$ Table $1 \mathrm{C}$ presents means for these outcomes.
} 
importance. For instance, in 1995, 28 percent of state YRBS respondents who smoked obtained their cigarettes through borrowing; by 2009, 35 percent obtained their cigarettes through borrowing. Figure 4 shows how young smokers usually obtained their cigarettes based on weighted national YRBS data. Again, the trends look very similar to those in the state YRBS, adding to our confidence that these two surveys captured the same broad influences.

Although an increasingly large proportion of young smokers came to rely on the social market during a period when state cigarette taxes rose sharply, it is of course possible that other forces were behind these concurrent trends. Our empirical strategy, if successful, will isolate the effect of cigarette taxes on the social market.

\section{THE EMPIRICAL MODEL}

We begin by using state YRBS data for the period 1995-2009 to estimate a standard logit model in which the probability that a respondent, $i$, smoked within 30 days of their interview is given by:

$$
\operatorname{Pr}\left(y_{i}=1\right)=\frac{\exp ^{\beta^{\prime} x_{i}}}{1+\exp ^{\beta^{\prime} x_{i}}} .
$$

Following Carpenter and Cook (2008), the vector $x_{i}$ includes the cigarette tax in respondent $i$ 's state of residence as well as measures of race, sex, age, grade, clean indoor air law indicators, and the state unemployment rate. ${ }^{14}$ In addition, the regressions include state and year fixed effects. This model can easily be modified to examine the determinants of other smoking outcomes.

Next, we turn our attention to how youths usually obtained their cigarettes. As noted, Katzman, Markowitz and McGeary (2007) used data from the national YRBS for the

\footnotetext{
${ }^{14}$ Information on clean air indoor laws was provided by Carpenter and Cook and was originally coded by the ImpacTeen program sponsored by the Robert Wood Johnson Foundation. It is available at: http://www.impacteen.org/tobaccodata.htm. Information on per-pack state cigarette taxes was obtained from The Tax Burden on Tobacco: Historical Compilation (Orzechowsku and Walker 2009). Cigarette taxes were put in 2005 dollars using the Consumer Price Index. Descriptive statistics for selected control variables are presented in Appendix Table 4.
} 
period 1995-2001. Restricting their sample respondents who had smoked at least once in their lives, they estimated the following multinomial logistic model:

$$
\operatorname{Pr}\left(y_{i}=j\right)=\frac{\exp ^{\beta_{j}^{\prime} x_{i}}}{1+\sum_{j=1}^{J} \exp ^{\beta_{j}^{\prime} x_{i}}},
$$

where $j$ indexes the choice between borrowing, purchasing, and not smoking. They found little evidence that cigarette taxes were related to borrowing, and concluded that cigarette tax increases "are ineffective in reaching the group of light smokers who primarily obtain cigarettes through the social market, thus indicating that alternative measures should be explored in an effort to reduce the number of smokers in the future" (p. 1025). ${ }^{15}$

However, there is reason to take this conclusion with a grain of salt. Katzman, Markowitz and McGeary (2007) had available to them data from a period when there was limited within-state variation in cigarette taxes. Moreover, many states contributed only a few hundred observations to the national YRBS in any given year. As a result of these limitations, Katzman, Markowitz and McGeary (2007) were forced to rely on cross-state variation in taxes for identification and could not control for difficult-to-measure factors at the state level such as anti-smoking sentiment. ${ }^{16}$

Our empirical strategy is similar to that adopted by Katzman, Markowitz and McGeary (2007), who focused on the decision to borrow versus buy cigarettes. Specifi-

\footnotetext{
${ }^{15}$ Katzman, Markowitz and McGeary (2007) also examined a sample composed of all respondents regardless of smoking history. The results were similar to the results obtained when the sample was restricted to respondents who had smoked at least once in their lives. That is, there was little evidence that cigarette taxes were related to borrowing. In both the full sample and the sample composed of "light smokers", cigarette taxes were negatively related to the probability of buying cigarettes.

${ }^{16}$ Although these authors attempted to "further account for the potential endogeneity of prices and taxes" by including state fixed effects as controls, they discovered that

the inclusion of state fixed effects in conjunction with the time fixed effects eliminated virtually all the independent variation in cigarette prices. An ordinary least squares regression of cigarette prices on state and time effects alone yields an $\mathrm{R} 2$ of 0.97 . The $\mathrm{R} 2$ when taxes are considered is 0.87 . These results imply that there is not enough variation within states to include state fixed effects in the models (Katzman, Markowitz and McGeary 2007, p. 1030).
} 
cally, in order to examine the relationship between taxes and how youths obtained their cigarettes, we estimate a multinomial logistic model with state and year fixed effects, but outcomes that correspond to those introduced in the previous section. Estimation of this model is aided by the fact that our data often contain more observations per state-year than do the national YRBS data. It is also aided by the fact that almost every state increased its per-pack cigarette tax during the 2000s. ${ }^{17}$

\section{THE RESULTS}

Regression results are presented in Tables 2 through 10. Standard errors corrected for clustering at the state level are reported (Bertrand, Duflo and Mullainathan 2004). Although we always employ the controls proposed by Carpenter and Cook (2008), our focus is on estimating the impact of a one-dollar increase in state cigarette taxes. ${ }^{18}$

\subsection{Cigarette taxes and participation}

Table 2 presents estimated marginal probabilities from the standard logit model described above. We examine the effects of cigarette tax increases on three binary outcomes: smoking participation, frequent smoking, and everyday smoking.

When the full sample of 9th through 12th graders is examined, a one-dollar increase in the cigarette tax is associated with a 9 percent $(0.022 / 0.246)$ reduction in youth smoking participation, a 14 percent $(0.017 / 0.12)$ reduction frequent smoking, and an 18 percent (0.016/0.088) reduction everyday smoking.

\footnotetext{
${ }^{17}$ The exceptions are California, Missouri, North Dakota, and South Carolina. As a result of these increases in the per-pack cigarette tax, we are able to introduce state fixed effects without losing as much identifying variation as did Katzman, Markowitz and McGeary (2007). In fact, an ordinary least squares regression of cigarette taxes on state and time effects for the period 1995-2009 yields an R2 of 0.78, considerably lower than the R2 obtained by Katzman, Markowitz and McGeary (2007).

${ }^{18}$ The mean cigarette tax was 69.3 cents in our sample. Estimated marginal probabilities (from a smoking participation equation) are shown in Appendix Table 5. We find that blacks and Hispanics are less likely to smoke than whites. In addition, we find that age is positively related to the probability of smoking. These results are consistent with those of previous studies (Chaloupka and Grossman 1996; Carpenter and Cook 2007). Male 14- and 15-year-olds are less likely to smoke than female 14- and 15-year-olds, but male 18-year-olds are more likely to smoke than female 18-year-olds. When we estimated a smoking participation equation using national YRBS data, the results were similar to those presented in Appendix Table 5.
} 
These estimates are comparable in magnitude to those obtained by Carpenter and Cook (2008) when using state YRBS data for the period 1993-2005. Carpenter and Cook (2008) found that a one-dollar increase in cigarette taxes was associated with a 9 percent reduction in youth smoking participation and an 18 percent reduction in frequent smoking. Using data from the national YRBS for the period 1991-2005, Carpenter and Cook (2008) found that a one-dollar increase in cigarette taxes was associated with a 20 percent reduction in youth smoking participation and a 30 percent reduction in frequent smoking. The comparison of our estimates with those of Carpenter and Cook (2008) suggests that the responsiveness of youth smoking to cigarette tax increases has remained roughly constant through the 1990 s and 2000s. ${ }^{19}$

Fourteen- and 15-year-old smokers relied more heavily on the social market than their older peers. In fact, only 11 percent of 14- and 15-year-old state YRBS respondents who smoked usually obtained their cigarettes through direct purchase from a commercial establishment. ${ }^{20}$ Despite this reliance on the social market, cigarette taxes appear to have had comparable effects on the smoking behavior of younger teenagers and their older counterparts. When the sample is restricted to 14- and 15-year-olds, a one-dollar increase in the state cigarette tax is associated with an 11 percent $(0.022 / 0.196)$ reduction in participation and a 17 percent (0.013/0.077) reduction in frequent smoking. In comparison, among 16through 17-year-olds, a one-dollar tax increase is associated with a 7 percent $(0.018 / 0.263)$ reduction in participation and a 13 percent $(0.017 / 0.130)$ reduction in frequent smoking. Among 18-year-olds, a one-dollar tax increase is associated with a 12 percent $(0.039 / 0.319)$

\footnotetext{
${ }^{19}$ However, it is interesting to note that when we restrict our attention to state YRBS data for the period 2001-2009, there is very little evidence that cigarette taxes are related to smoking behavior. For instance, among 14- through 18-year-olds, a one-dollar increase in the cigarette tax is associated with a statistically insignificant 0.08 decrease in smoking participation and a statistically insignificant 0.09 decrease in frequent smoking.

${ }^{20}$ Younger teens presumably had more difficulty buying from commercial outlets. The minimum legal purchase age (MLPA) for cigarette was 18 in all but a handful of states (Alabama, Alaska, New Jersey, Pennsylvania, and Utah) during the period 1995-2009, although the state legislatures of Massachusetts and Illinois have recently debated raising the MLPA to 19. If the full cost of obtaining cigarettes includes the time and effort spent trying to evade MLPA restrictions, then a one-dollar increase in the cigarette tax would represent a smaller proportional increase in cost for younger teens than for older teens. Thus, we might expect cigarette tax increases to have a smaller impact on the smoking behavior of younger teens.
} 
reduction in participation and an 18 percent $(0.031 / 0.177)$ reduction in frequent smoking.

Next, we explore the sensitivity of these estimates to controlling for anti-smoking sentiment measured using the Tobacco Use Supplements of the Current Population Survey (CPS). The CPS asked respondents about their views on the promotion and advertising of tobacco products, policies that restrict smoking on public or private property, and whether they permit smoking in their homes. DeCicca et al. (2008) used the answers to these questions to produce a measure of anti-smoking sentiment at the state level. ${ }^{21}$

The results of this exercise are reported in the top panel of Table 3. Although our estimates of the relationship between cigarette taxes and smoking are, in a few cases, slightly reduced in magnitude, it is clear that anti-smoking sentiment is not the primary diver of the results reported in Table 2 .

Finally, we explore the sensitivity of the estimated relationship between taxes and smoking to including state-specific linear time trends on the right-hand-side. Their inclusion is intended to control for tastes and other determinants of smoking that moved smoothly over time. The bottom panel of Table 3 reports the results of this exercise. Controlling for state-specific linear time trends often reduces the precision of our estimates; nevertheless, there is a clear negative relationship between taxes and smoking.

Taken together, the results in Tables 2 and 3 provide strong evidence that state cigarette tax increases during the 1995-2009 period led to reductions in youth smoking. Despite the fact that 14-and 15-year-olds relied primarily on the social market for cigarettes, their response to these tax increases appears to have been comparable to that of their older peers who relied more heavily on direct purchase from a commercial establishment.

\subsection{Cigarette taxes and the social market}

In Table 4, we present estimated marginal probabilities from the multinomial logit

\footnotetext{
${ }^{21}$ The anti-smoking sentiment variable was provided to us by DeCicca, Kenkel, Mathios, Shin, and Lim (i.e., DeCicca et al. 2008). As noted by DeCicca, Kenkel and Mathios (2008, p. 909), "[i]f public anti-smoking sentiment is itself an important determinant of smoking, failing to control for differences in anti-smoking sentiment across states will bias estimates towards finding stronger tax-responsiveness."
} 
model. The baseline category is composed of non-smokers. Our results suggest that, in addition to discouraging smoking, cigarette taxes influence how youth obtain their cigarettes, presumably through their impact on relative cost. The largest effect is on third-party purchase. A one-dollar increase in taxes is associated with a 20 percent $(0.013 / 0.065)$ reduction in the probability that 14- through 18-year-olds usually "gave someone else money" to buy cigarettes. In addition, a one-dollar increase in taxes is associated with a 9 percent $(0.006 / 0.070)$ reduction in the probability that they obtained cigarettes through direct purchase. ${ }^{22}$ There is little evidence in the full sample that taxes are associated with borrowing or using other sources including vending machines and stealing.

Among 14- and 15-year-olds, taxes appear to work almost entirely through the social market. A one-dollar increase in the cigarette tax is associated with an 14 percent $(0.010 / 0.074)$ reduction in the probability that 14- and 15-year-olds borrowed or "bummed" cigarettes. It is also associated with an 11 percent $(0.007 / 0.061)$ reduction in the probability that they usually obtained their cigarettes through third-party purchase. The estimated relationship between taxes and direct purchase is small and not statistically significant at conventional levels. This pattern of results is consistent with the hypothesis that younger teens were, in effect, squeezed out of the social market as newly imposed cigarette taxes were passed on to consumers in the form of higher prices.

When we turn our focus to older teenagers, who presumably had greater status or social capital on which to draw, we find almost no evidence that borrowing was negatively impacted by cigarette taxes. Instead, cigarette taxes appear to work primarily through third-party and direct purchase. When the sample is restricted to 16-and 17-year-olds, a one-dollar increase in cigarette taxes is associated with a 22 percent $(0.018 / 0.083)$ reduction in the probability of third-party purchase and an 11 percent $(0.007 / 0.061)$ reduction in the probability of direct purchase. Among 18-year-olds, who could legally buy cigarettes in all

\footnotetext{
${ }^{22}$ The estimated marginal effect of taxes on third-party purchase is different from the estimated marginal effect on direct purchase at the 0.05 level.
} 
but a handful of states, cigarette taxes appear to work primarily through direct purchase. ${ }^{23}$

In Table 5, we examine the robustness of the multinomial logit estimates to controlling for anti-smoking sentiment and state-specific linear time trends. These results confirm that an increase in cigarette taxes is associated with a reduction in the probability of thirdparty purchase. However, the estimated relationship between cigarette taxes and borrowing by 14- and 15-year-olds becomes smaller and statistically indistinguishable from zero at conventional levels when state-specific trends are included. Even controlling for state-specific linear trends, there is still strong evidence that cigarette taxes reduce smoking participation by 18-year-olds primarily through direct purchase.

\subsection{Vending machine, stealing and other methods of obtaining cigarettes}

A 1993 study by the Texas Department of Public Health found that most vending machines were unattended, and attempts by underage consumers to purchase cigarettes from vending machines were almost always successful (Centers for Disease Control and Prevention 1994). During the mid-1990s, a number of states and localities mandated electronic locking devices on vending machines, increased licensing fees for vending machines, and raised fines on businesses that did not monitor vending machines. In March 2006, new federal regulations required vending machines to be placed within sight of service counters, and a June 2010 Food and Drug Administration regulation restricted vending machine access to locations where patrons must be at least 18 years of age, such as bars, casinos and strip clubs.

In Figure 5, we show the trend in vending machine use among state YRBS respondents who smoked. With the introduction of the new restrictions described above, reliance on vending machines appears to have declined (although it was never particularly high). In 1995, two percent of state YRBS respondents who smoked usually obtained their cigarettes

\footnotetext{
${ }^{23}$ The multinomial logit estimates suggest that a one-dollar increase in cigarette taxes is associated with a 0.034 reduction in the probability of smoking participation among 18-year-olds. A one-dollar increase in the cigarette tax is also associated with small, statistically insignificant increases in the probability of borrowing and the probability of obtaining cigarettes through vending machine purchase, stealing or other means, but a 0.038 reduction in the probability of direct purchase and a 0.008 reduction in the probability of third-party purchase.
} 
via vending machine purchase; by 2009, a little over one percent obtained their cigarettes via vending machine purchase.

In contrast, reliance on other methods to obtain cigarettes increased during the 19952009 period, perhaps due to internet sales (on which the state tax is effectively zero). ${ }^{24}$ In 1995, 7 percent of state YRBS respondents who smoked reported usually using "some other way" to obtain their cigarettes; by 2009, 11 percent belonged to this category (Figure 5). There was also an increase in stealing. In 1995, 4 percent of state YRBS respondents who smoked reported that they usually "took them from a store or family member"; by 2009, 5 percent reported stealing their cigarettes (Figure 5).

Could these trends have been, at least in part, the result of state cigarette tax increases taking place between 1995 and 2009? In an effort to answer this question, we estimate two variations on our original multinomial logit model: in the first, stealing cigarettes is treated as a separate category; in the second, obtaining cigarettes "some other way" is treated as a separate category (the baseline category is, in both models, composed of state YRBS respondents who did not smoke). ${ }^{25}$

The results of these experiments are reported in Tables 6 and 7 . When stealing is treated as a separate category, there is evidence that its use is negatively related to taxes, suggesting that the increase in stealing over the period 1995-2009 was due to another factor. However, when "some other way" is treated as a separate category, there is evidence that its use by 18-year-olds is positively related to taxes, a result that is consistent with the fact that 18-year-olds have fewer obstacles to buying online than their younger peers. ${ }^{26}$

\footnotetext{
${ }^{24}$ According to Goolsbee, Lovenheim and Slemrod (2010), although legally required to pay state cigarette taxes, online buyers rarely comply with this requirement. Data with regard to the volume of online cigarette sales are nonexistent, but "[v]irtually all expert observers agree...that online cigarette sales have been growing very rapidly in the last several years" (Goolsbee, Lovenheim, and Slemrod 2010, p.135).

${ }^{25}$ There were too few respondents who reported that they usually obtained their cigarettes from vending machines to constitute a separate category.

${ }^{26}$ Although cigarette retailers are required to verify the age of their customers, internet vendors often fail to comply with this requirement. Nonetheless, internet sales to minors are still at a low level (Ribisl et al. 2007). The results of Goolsbee, Lovenheim and Slemrod (2010) suggest that internet users are particularly sensitive to cigarette taxes.
} 


\subsection{Conditional estimates}

Katzman, Markowitz and McGeary (2007) focused their attention on youth who had smoked at least once in their lives, arguing that they had demonstrated a preference for smoking and should therefore be "considered at risk for purchasing cigarettes" (p. 1031). Forty-four percent of state YRBS respondents reported that they had never experimented with cigarettes. In Table 8 we report marginal effects based on a sample from which these respondents were excluded. The results look similar to those reported in Tables 4 and 5: among 14- through 18-year-old respondents who had smoked at least once in their lives, a one-dollar increase in the cigarette tax is associated with a statistically significant reduction in third-party purchase; among 14- and 15 year-olds who had smoked at least once, it is associated with an 8 percent $(0.013 / 0.154)$ reduction in the probability of borrowing, but this estimate is not significant at conventional levels; and among 18-year-olds who smoked at least once, it is associated with a 30 percent $(0.008 / 0.027)$ increase in the probability of obtaining cigarettes through other means including vending machines and stealing. ${ }^{27}$

Next, we focus on frequent and everyday smokers, who may have more social capital on which to draw as compared to lighter smokers. Tables 9 and 10 present multinomial estimates of the relationship between taxes and how frequent and everyday smokers obtain their cigarettes. The baseline category is composed of frequent/everyday smokers who reported usually obtaining cigarettes though direct purchase. We note that caution should be exercised when interpreting the estimates presented in Tables 9 and 10. Because we do not have longitudinal data, we cannot explore changes in the behavior of frequent and everyday smokers in response to tax increases. Rather, we are limited to examining a select group of frequent/everyday smokers who were arguably more committed to their habit than those who quit or reduced their smoking intensity as taxes went up.

The results in Table 9 provide little evidence of a relationship between taxes and how

\footnotetext{
${ }^{27}$ Appendix Table 6 A shows where state YRBS respondents who smoked at least once in their lives usually obtained their cigarettes.
} 


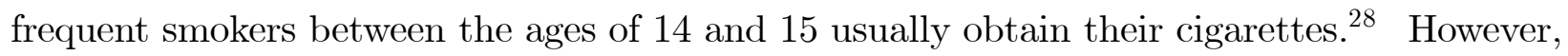
when the sample is restricted to 16- and 17-year-old frequent smokers, a one-dollar increase in cigarette taxes is associated with an 8 percent $(0.035 / 0.431)$ reduction in the probability of third-party purchase, but a 7 percent $(0.023 / 0.317)$ increase in the probability of direct purchase. ${ }^{29}$ This pattern of results suggests that some frequent smokers, perhaps those without sufficient social capital, actually turn to direct purchase from a commercial establishment as the per-pack price of cigarettes rises. Direct purchase would be a natural alternative to third-party purchase for teenagers who, for instance, lacked friends or acquaintances able to legally purchase and then resell cigarettes. Among 18-year-old frequent smokers, a onedollar increase in cigarette taxes is associated with a 39 percent $(0.018 / 0.046)$ reduction in the probability of third-party purchase.

The focus of Table 10 is on respondents who reported smoking everyday for the past month. ${ }^{30}$ Among everyday smokers ages 14 through 18, we find that a one-dollar increase in cigarette taxes is associated with a 10 percent $(0.036 / 0.357)$ reduction in the probability of third-party purchase. When the sample is restricted to 16- and 17-year-old everyday smokers, a one-dollar increase in the cigarette tax is associated with an 11 percent $(0.046 / 0.423)$ reduction in the probability of third-party purchase, but an 11 percent (0.035/0.332) increase in the probability of direct purchase. ${ }^{31}$ Interestingly, when the sample is restricted to 18 year-old daily smokers, who presumably had the most social capital on which to draw of any group in our sample, a one-dollar increase in the cigarette tax is associated with a 71 percent $(0.017 / 0.024)$ increase in the probability of borrowing. In addition, a one-dollar increase in the cigarette tax is associated with a 31 percent $(0.019 / 0.061)$ increase in the

\footnotetext{
${ }^{28}$ Although the results in Table 9 suggest that younger frequent smokers were less sensitive to taxes than their older counterparts, we cannot formally reject the hypothesis that our estimated effects are equal across the three age groups.

${ }^{29}$ Appendix Table 6B shows where state YRBS respondents who smoked frequently usually obtained their cigarettes. The estimated relationship between taxes and direct purchase by 16- and 17-year-old frequent smokers is statistically significant at the 0.05 level (standard error $=0.008$ ).

${ }^{30}$ Appendix Table 6C shows where state YRBS respondents who smoked everyday usually obtained their cigarettes.

${ }^{31}$ The estimated relationship between taxes and direct purchase by 16- and 17-year-old everyday smokers is statistically significant at the 0.05 level (standard error $=0.017$ ).
} 
probability that 18-year-old everyday smokers usually obtained cigarettes through other sources including vending machines and stealing. ${ }^{32}$

\section{CONCLUSION}

Carpenter and Cook (2008) noted that most high school students obtain their cigarettes from social sources and are therefore, at least to some degree, insulated from increases in the price charged by commercial establishments. Nevertheless, their results suggest that recent cigarette tax increases have had the effect of reducing youth smoking participation. Carpenter and Cook (2008) speculated that "[a]n increase in cigarette taxes may make potential sources more reluctant to provide youths with cigarettes" (p. 298), but acknowledged that, without better data, it was impossible to pinpoint the mechanism (or mechanisms) through which tax increases led to reduced smoking participation.

The goal of this study was to look inside this "black box" by exploring the impact of cigarette taxes on the social market using state YRBS data for the period 1995-2009 . Did tax increases encourage participation in the social market or did they dampen borrowing and/or third-party purchases? If increases in the cigarette excise tax are not an effective means of reducing social market participation, it would argue for the development of policies aimed specifically at discouraging adolescents from borrowing, stealing, and buying from friends, family and strangers (Friend et al. 2001; Katzman, Markowitz and McGeary 2007).

Exploiting recent and sizeable increases in state excise taxes on cigarettes, we find evidence that teenagers respond to having to pay more to smoke by reducing their reliance on third-party purchases, an important component of the social market. In fact, it appears that tax increases taking place between 1995 and 2009 reduced youth smoking participation primarily through third-party purchases.

\footnotetext{
${ }^{32}$ See Appendix Tables 7-10 for conditional estimates in which "some other way" and stealing are treated as separate categories. Among 18-year-old frequent and everyday smokers, we find that taxes are positively related to using "some other way" to obtain cigarettes. We find no evidence that sealing by frequent and everyday smokers is related to taxes.
} 
Among 14- through 15-year-olds, we find that cigarette taxes are negatively associated with borrowing, a result that suggests that some younger smokers do not have sufficient status or social capital to participate in the social market: as cigarette taxes are passed on to consumers in the form of higher prices, they appear increasingly likely to encounter difficulties borrowing. In contrast, we find that tax increases have little effect on borrowing by older teenagers, but are associated with a small reduction in the probability that 16and 17-year-olds directly purchase cigarettes from a commercial establishment, and a larger reduction in the probability that 18-year-olds directly purchase their cigarettes. Finally, we find evidence that taxes are positively related to the probability that 18-year-olds use "some other way" to buy their cigarettes, a result that is consistent with the fact that 18-year-olds have fewer obstacles to buying online than their younger peers.

\section{References}

[1] Bertrand, Marianne, Esther Duflo, and Sendhil Mullainathan. 2004. "How Much Should We Trust Differences-in-Differences Estimates?" Quarterly Journal of Economics, Vol. 119, No. 1, pp. 249-75.

[2] Barnett, Paul G., Theodore E. Keeler, and Teh-wei Hu. 1995. "Oligopoly Structure and the Incidence of Cigarette Excise Taxes." Journal of Public Economics, Vol. 57, No. 3, pp. $457-70$

[3] Bishai, David M., Dan Mercer, and Athena Tapales. 2005. "Can Government Policies Help Adolescents Avoid Risky Behavior?" Preventive Medicine, Vol. 40, No. 2, pp. 197-202.

[4] Bourdieu, Pierre. 1986. "The Forms of Capital." In, J. Richardson (ed.), Handbook of Theory and Research for the Sociology of Education. New York: Greenwood, pp. 241-58.

[5] Brown, Timothy T., Richard M. Scheffler, Sukyong Seo, and Mary Reed. 2006. "The Empirical Relationship between Community Social Capital and the Demand for Cigarettes." Health Economics, Vol. 15, No. 11, pp. 1159-72.

[6] Carpenter, Christopher, and Philip J. Cook. 2007. "Cigarette Taxes and Youth Smoking: New Evidence from National, State, and Local Youth Risk Behavior Surveys." Working paper available at: http://web.gsm.uci.edu/ kittc/Carpenter-Cook-JHE-CigaretteTaxes-Youth-Smoking-YRBS.pdf 
[7] Carpenter, Christopher, and Philip J. Cook. 2008. "Cigarette Taxes and Youth Smoking: New Evidence from National, State, and Local Youth Risk Behavior Surveys." Journal of Health Economics, Vol. 27, No. 2, pp. 287-99.

[8] Centers for Disease Control and Prevention. 1994. "Minors' Access to Cigarette Vending Machines - Texas." Morbidity and Mortality Weekly Report, Vol. 43, No. 34, pp. 625-627.

[9] Chaloupka, Frank, and Michael Grossman. 1996. "Price, Tobacco Control Policies, and Youth Smoking." NBER Working Paper No. 5740.

[10] Croghan, Emma, Aveyard, P., Griffin, C., and Cheng, K.K. 2003. "The Importance of Social Sources of Cigarettes to High School Students." Tobacco Control, Vol. 12, No. 1, pp. $67-73$.

[11] Coleman, James S. 1988. "Social Capital in the Creation of Human Capital." The American Journal of Sociology, Vol. 94, Supplement: Organizations and Institutions: Sociological and Economic Approaches to the Analysis of Social Structure, pp. S95-S120.

[12] DeCicca, Philip, Donald Kenkel, and Alan Mathios. 2002. "Putting Out the Fires: Will Higher Taxes Reduce the Onset of Youth Smoking?" Journal of Political Economy, Vol. 110, No. 1, pp. 144-69.

[13] DeCicca, Philip, Donald Kenkel, and Alan Mathios. 2008. "Cigarette Taxes and the Transition from Youth to Adult Smoking: Smoking Initiation, Cessation, and Participation." Journal of Health Economics, Vol. 27, No. 4, pp. 904-17.

[14] Decicca, Philip, Donald Kenkel, Alan Mathios, Yoon-Jeong Shin, and Jae-Young Lim. 2008. "Youth Smoking, Cigarette Prices, and Anti-Smoking Sentiment." Health Economics, Vol. 17, No. 6, pp.733-41.

[15] Decicca, Philip, Donald Kenkel, and Feng Liu. 2010 "Who Pays Cigarette Taxes? The Impact of Consumer Price Search." Working paper available at: http://www.economics.mcmaster.ca/documents/Who-20Pays-20Cigarette20Taxes_March-202010.pdf

[16] Evans, William N., Jeanne S. Ringel, and Diana Stech. 1999. "Tobacco Taxes and Public Policy to Discourage Smoking." Tax Policy and the Economy, Vol. 13, pp. 1-55.

[17] Forster, J., Chen, V., Blaine, T., Perry, C., and Toomey, T. 2003. "Social Exchange of Cigarettes by Youth." Tobacco Control, Vol. 12, No 2, pp. 148-54.

[18] Franz, Gregor A. 2008. "Price Effects on the Smoking Behaviour of Adult Age Groups." Public Health, Vol. 122, No. 12, pp.1343-48.

[19] Friend, Karen, Maria Carmona, Philip Wilbur, and David Levy. 2001. "Youths' Social Sources of Cigarettes: the Limits of Youth-Access Policies." Contemporary Drug Problems, Vol. 28, pp. 507-26. 
[20] Goolsbee, Austan, Michael F. Lovenheim, and Joel Slemrod. 2010. "Playing with Fire: Cigarettes, Taxes, and Competition from the Internet." American Economic Journal: Economic Policy, Vol. 2, No. 1, pp. 131-54.

[21] Green, William. 2004. "The Behaviour of the Maximum Likelihood Estimator of Limited Dependent Variable Models in the Presence of Fixed Effects." The Econometrics Journal, Vol. 7, No.1, pp. 98-119.

[22] Gruber, Jonathan and Jonathan Zinman. 2001. "Youth Smoking in the United States: Evidence and Implications." In: J. Gruber, (ed.), Risky Behavior Among Youths: An Economic Analysis. University of Chicago Press: Chicago, pp. 69-120.

[23] Harris, Jeffrey E., and Sandra W. Chan. 1998. "The Continuum-of-Addiction: Cigarette Smoking in Relation to Price among Americans Aged 15-29." Health Economics Letters, Vol. 2, No. 2, pp. 3-12.

[24] Katzman, Brett, Sara Markowitz, and Kerry Anne McGeary. 2007."An Empirical Investigation of the Social Market for Cigarettes." Health Economics, Vol. 16, No. 10, pp. 1025-39.

[25] Lancaster, Tony. 2000. "The Incidental Parameter Problem since 1948." Journal of Econometrics, Vol. 94, No. 2, 391-413.

[26] Lindström, Martin. 2003. "Social Capital and the Miniaturization of Community among Daily and Intermittent Smokers: a Population-Based Study." Preventive Medicine, Vol. 36, No. 2, pp. 177-84.

[27] Neyman, J., Scott, Elizabeth.L., 1948. "Consistent Estimation from Partially Consistent Observations." Econometrica, Vol 16, No. 1, pp. 1-32.

[28] Orzechowski, William and Robert Walker. 2009. The Tax Burden on Tobacco: Historical Compilation, Vol. 43, Arlington, VA.

[29] Ribisl, Kurt M. 2003. "Social Sources of Cigarettes for Youth: Broadening the Research Base." Tobacco Control, Vol. 12, No. 2, pp. 115-16.

[30] Ribisl, Kurt M., Rebecca S. Williams, Annice E. Kim. 2007. Policy Brief on: Internet Cigarette Sales. Substance Abuse Policy Research Program. Available at: http://www.saprp.org/knowledgeassets/pdf/InternetCigSales_PolicyBriefReport.pdf

[31] Sullivan, Ryan and Andrew Hanson. 2009. "The Incidence of Tobacco Taxation: Evidence from Geographic Micro-Level Data." The National Tax Journal, Vol. 62, No. 4, pp. 677-98.

[32] Woolcock, Michael and Deepa Narayan. 2000. "Social Capital: Implications for Development Theory, Research, and Policy." The World Bank Research Observer, Vol. 15, No. 2, pp. 225-49. 
Figure 1: Smoking Participation Among 10th Graders

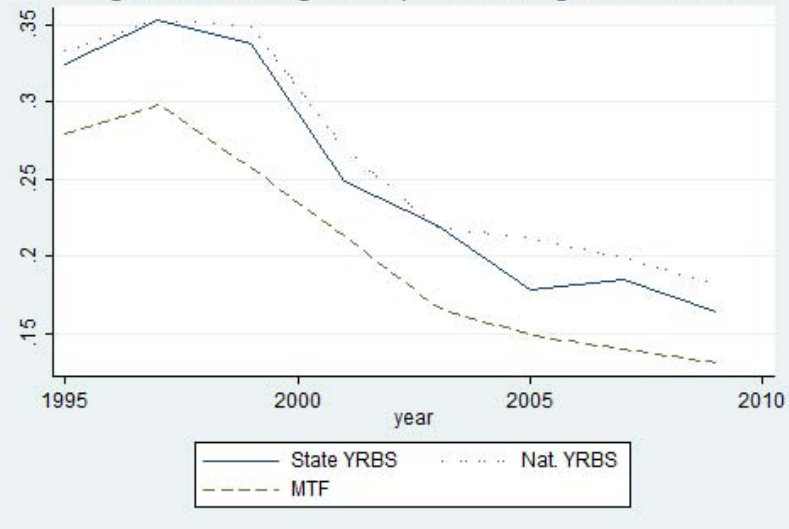

Figure 2: Smoking Participation Among 12th Graders

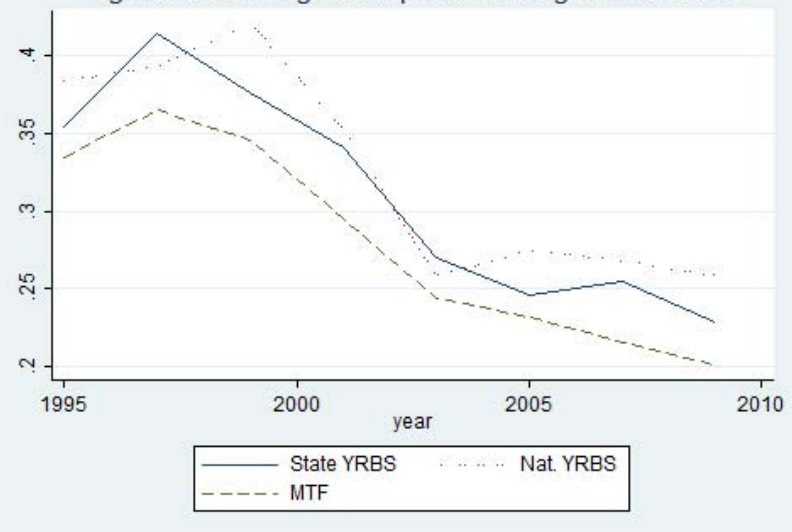

Figure 3: Usual Method of Obtaining Cigarettes Among State YRBS Respondents who Smoked, 1995-2009

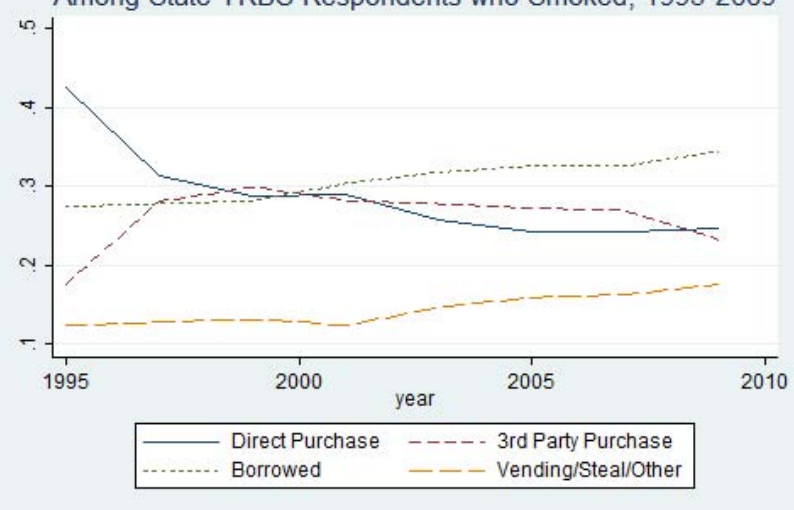


Figure 4: Usual Method of Obtaining Cigarettes

Among National YRBS Respondents who Smoked, 1995-2009

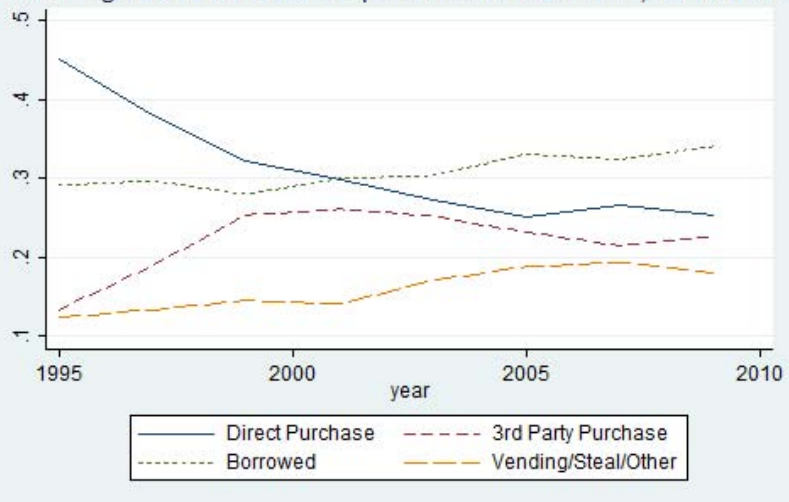

Figure 5: Trends in Vending Machine Purchase, Stealing And Other Methods of Obtaining Cigarettes Among State YRBS Respondents who Smoked 1995-2009

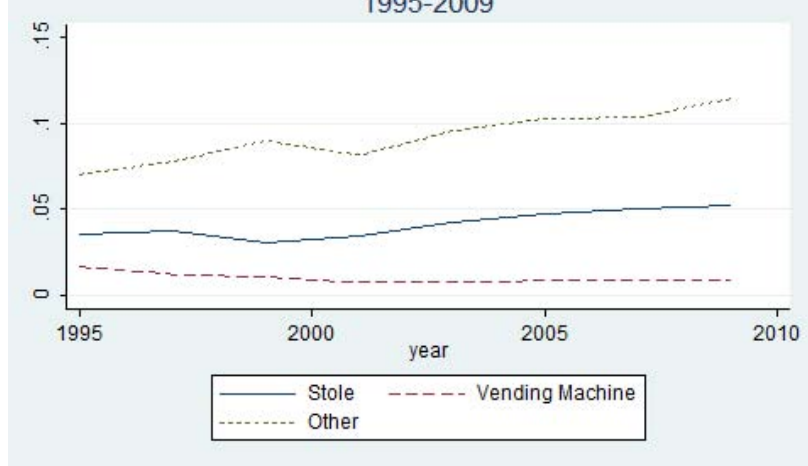


Table 1A. Smoking Behavior by Age of State YRBS Respondent

\begin{tabular}{|c|c|c|c|}
\hline & Participation & Frequent Smoking & Everyday Smoking \\
\hline $\begin{array}{l}\text { All Ages } \\
{[\mathrm{N}=235,549]}\end{array}$ & 0.246 & 0.120 & 0.088 \\
\hline $\begin{array}{l}\text { Ages } 14 \text { and } 15 \\
{[\mathrm{~N}=85,805]}\end{array}$ & 0.196 & 0.077 & 0.054 \\
\hline $\begin{array}{l}\text { Ages } \mathbf{1 6} \text { and } \mathbf{1 7} \\
{[\mathrm{N}=118,994]}\end{array}$ & 0.263 & 0.130 & 0.099 \\
\hline $\begin{array}{l}\text { Age 18 } \\
{[\mathrm{N}=30,750]}\end{array}$ & 0.319 & 0.177 & 0.141 \\
\hline \multicolumn{4}{|c|}{ Note: Based on unweighted state YRBS data for the period 1995-2009. } \\
\hline \multicolumn{4}{|c|}{ Table 1B. Smoking Behavior by Age c } \\
\hline & Participation & Frequent Smoking & Everyday Smoking \\
\hline $\begin{array}{l}\text { All Ages } \\
{[\mathrm{N}=102,609]}\end{array}$ & 0.272 & 0.121 & 0.091 \\
\hline $\begin{array}{l}\text { Ages } \mathbf{1 4} \text { and } \mathbf{1 5} \\
{[\mathrm{N}=32,217]}\end{array}$ & 0.212 & 0.074 & 0.053 \\
\hline $\begin{array}{l}\text { Ages } \mathbf{1 6} \text { and } \mathbf{1 7} \\
{[\mathrm{N}=53,473]}\end{array}$ & 0.291 & 0.136 & 0.102 \\
\hline $\begin{array}{l}\text { Age 18 } \\
{[\mathrm{N}=16,919]}\end{array}$ & 0.354 & 0.185 & 0.146 \\
\hline
\end{tabular}


Table 1C. Method of Obtaining Cigarettes by Age of State YRBS Respondent

\begin{tabular}{|c|c|c|c|c|}
\hline & Direct Purchase & $\begin{array}{c}\text { Third-Party } \\
\text { Purchase }\end{array}$ & $\begin{array}{l}\text { Buming or } \\
\text { Borrowing }\end{array}$ & $\begin{array}{l}\text { Vending Machine, } \\
\text { Stealing or Other }\end{array}$ \\
\hline $\begin{array}{l}\text { All Ages } \\
{[\mathrm{N}=235,549]}\end{array}$ & 0.070 & 0.065 & 0.076 & 0.036 \\
\hline $\begin{array}{l}\text { Ages } 14 \text { and } 15 \\
{[\mathrm{~N}=85,805]}\end{array}$ & 0.022 & 0.061 & 0.074 & 0.041 \\
\hline $\begin{array}{l}\text { Ages } \mathbf{1 6} \text { and } \mathbf{1 7} \\
{[\mathrm{N}=118,994]}\end{array}$ & 0.061 & 0.083 & 0.084 & 0.036 \\
\hline $\begin{array}{l}\text { Age } 18 \\
{[\mathrm{~N}=30,750]}\end{array}$ & 0.241 & 0.013 & 0.049 & 0.017 \\
\hline
\end{tabular}


Table 2. Logit Estimates of the Effect of a $\$ 1$ Increase in the Per-Pack Cigarette Tax on Youth Smoking

\begin{tabular}{lccc}
\hline \hline & & & \\
& Participation & Frequent Smoking & Everyday Smoking \\
\hline All Ages & $-0.022^{* * *}$ & $-0.017^{* * *}$ & $-0.016^{* * *}$ \\
{$[\mathrm{~N}=235,549]$} & $(0.007)$ & $(0.004)$ & $(0.004)$ \\
Ages 14 and 15 & $-0.022^{* * *}$ & $-0.013^{* * *}$ & $-0.013^{* * *}$ \\
{$[\mathrm{~N}=85,805]$} & $(0.006)$ & $(0.004)$ & $(0.004)$ \\
Ages 16 and $\mathbf{1 7}$ & $-0.018^{* *}$ & $-0.017^{* * *}$ & $-0.015^{* *}$ \\
{$[\mathrm{~N}=118,994]$} & $(0.009)$ & $(0.007)$ & $(0.006)$ \\
Age 18 & $-0.039^{* * *}$ & $-0.031^{* * *}$ & $-0.026^{* * *}$ \\
{$[\mathrm{~N}=30,750]$} & $(0.014)$ & $(0.009)$ & $(0.007)$ \\
\hline *Statistically significant at the 0.10 level; **statistically significant at the 0.05 level; \\
***statistically significant at the 0.01 level. & & \\
Notes: Based on unweighted state YRBS data for the period 1995-2009. Estimated \\
marginal probabilities are presented. Controls include state fixed effects, year fixed \\
effects, race, sex, age, grade, ImpacTeen clean-air laws, and the state unemployment \\
rate. Standard errors corrected for clustering at the state level are in parentheses.
\end{tabular}


Table 3. Logit Estimates of the Effect of a $\$ 1$ Increase in the Per-Pack Cigarette Tax on Youth Smoking

\begin{tabular}{|c|c|c|c|}
\hline \multicolumn{4}{|c|}{ Panel I: Controlling for Anti-Smoking Sentiment } \\
\hline & Participation & Frequent Smoking & Everyday Smoking \\
\hline All Ages & $-0.021^{* * *}$ & $-0.017^{* * *}$ & $-0.015^{* * *}$ \\
\hline$[\mathrm{N}=235,549]$ & $(0.007)$ & $(0.005)$ & $(0.004)$ \\
\hline Ages 14 and 15 & $-0.021^{* * *}$ & $-0.012^{* * *}$ & $-0.013^{* *}$ \\
\hline$[\mathrm{N}=85,805]$ & $(0.006)$ & $(0.004)$ & $(0.004)$ \\
\hline Ages 16 and 17 & $-0.019^{* *}$ & $-0.017^{* * *}$ & $-0.016^{* *}$ \\
\hline$[\mathrm{N}=118,994]$ & $(0.006)$ & $(0.006)$ & $(0.006)$ \\
\hline Age 18 & $-0.034^{* *}$ & $-0.027^{* *}$ & $-0.022^{* * *}$ \\
\hline$[\mathrm{N}=30,750]$ & $(0.014)$ & $(0.010)$ & $(0.008)$ \\
\hline \multicolumn{4}{|c|}{ Panel II: Controlling for State-Specific Linear Time Trends } \\
\hline All Ages & $-0.027^{* *}$ & $-0.023^{* * *}$ & $-0.022^{* * *}$ \\
\hline$[\mathrm{N}=235,549]$ & $(0.008)$ & $(0.006)$ & $(0.006)$ \\
\hline Ages 14 and 15 & $-0.018^{* *}$ & $-0.013^{*}$ & $-0.016^{*}$ \\
\hline$[\mathrm{N}=85,805]$ & $(0.008)$ & $(0.007)$ & $(0.009)$ \\
\hline Ages 16 and 17 & $-0.029^{* *}$ & $-0.023^{* * *}$ & $-0.022^{* *}$ \\
\hline$[\mathrm{N}=118,994]$ & $(0.012)$ & $(0.006)$ & $(0.005)$ \\
\hline Age 18 & $-0.046^{* * *}$ & $-0.051^{* * *}$ & $-0.039^{* * *}$ \\
\hline$[\mathrm{N}=30,750]$ & $(0.014)$ & $(0.013)$ & $(0.009)$ \\
\hline \multicolumn{4}{|c|}{$\begin{array}{l}{ }^{*} \text { Statistically significant at the } 0.10 \text { level; }{ }^{* *} \text { statistically significant at the } 0.05 \text { level; } \\
* * * \text { statistically significant at the } 0.01 \text { level. }\end{array}$} \\
\hline \multicolumn{4}{|c|}{$\begin{array}{l}\text { Notes: Based on unweighted state YRBS data for the period 1995-2009. Estimated } \\
\text { marginal probabilities are presented. Controls include state fixed effects, year fixed }\end{array}$} \\
\hline
\end{tabular}


Table 4. Multinomial Logit Estimates of the Effect of a $\$ 1$ Increase in the Per-Pack Cigarette Tax on How Youths Obtain Cigarettes

\begin{tabular}{lcccc}
\hline \hline & Direct Purchase & $\begin{array}{c}\text { Third-Party } \\
\text { Purchase }\end{array}$ & $\begin{array}{c}\text { Bumming or } \\
\text { Borrowing }\end{array}$ & $\begin{array}{c}\text { Vending Machine, } \\
\text { Stealing or Other }\end{array}$ \\
\hline All Ages & $-0.006^{*}$ & $-0.013^{* * *}$ & -0.004 & -0.003 \\
{$[\mathrm{~N}=235,549]$} & $(0.004)$ & $(0.003)$ & $(0.004)$ & $(0.002)$ \\
Ages 14 and 15 & -0.002 & $-0.007^{*}$ & $-0.010^{* *}$ & -0.006 \\
{$[\mathrm{~N}=85,805]$} & $(0.002)$ & $(0.004)$ & $(0.004)$ & $(0.005)$ \\
Ages 16 and 17 & $-0.007^{*}$ & $-0.018^{* * *}$ & -0.002 & -0.001 \\
{$[\mathrm{~N}=118,994]$} & $(0.004)$ & $(0.004)$ & $(0.004)$ & $(0.002)$ \\
Age 18 & $-0.038^{* *}$ & $-0.008^{* * *}$ & 0.001 & 0.003 \\
{$[\mathrm{~N}=30,750]$} & $(0.018)$ & $(0.002)$ & $(0.006)$ & $(0.003)$ \\
\hline
\end{tabular}

*Statistically significant at the 0.10 level; ${ }^{* *}$ statistically significant at the 0.05 level;

*** statistically significant at the 0.01 level.

Notes: Based on unweighted state YRBS data for the period 1995-2009. Estimated marginal probabilities are presented. Controls include state fixed effects, year fixed effects, race, sex, age, grade, ImpacTeen cleanair laws, and the state unemployment rate. Standard errors corrected for clustering at the state level are in parentheses. The baseline category is composed of respondents who did not smoke in the past 30 days. 
Table 5. Multinomial Logit Estimates of the Effect of a $\$ 1$ Increase in the Per-Pack Cigarette Tax on How Youths Obtain Cigarettes

\begin{tabular}{|c|c|c|c|c|}
\hline \multicolumn{5}{|c|}{ Panel I: Controlling for Anti-Smoking Sentiment } \\
\hline & Direct Purchase & $\begin{array}{l}\text { Third-Party } \\
\text { Purchase }\end{array}$ & $\begin{array}{l}\text { Bumming or } \\
\text { Borrowing }\end{array}$ & $\begin{array}{l}\text { Vending Machine, } \\
\text { Stealing or Other }\end{array}$ \\
\hline All Ages & -0.005 & $-0.012^{* * *}$ & $-0.005^{*}$ & $\begin{array}{l}-0.002 \\
(0.009)\end{array}$ \\
\hline$\left[\begin{array}{l}{[\mathrm{N}=235,549]} \\
\text { Ages } \mathbf{1 4} \text { and } \mathbf{1 5}\end{array}\right.$ & $\begin{array}{l}(0.004) \\
-0.002\end{array}$ & $\begin{array}{l}(0.003) \\
-0.007^{*}\end{array}$ & $\begin{array}{l}(0.003) \\
-0.010^{* *}\end{array}$ & $\begin{array}{l}(0.002) \\
-0.005\end{array}$ \\
\hline$[\mathrm{N}=85,805]$ & $(0.002)$ & $(0.004)$ & $(0.004)$ & $(0.005)$ \\
\hline Ages 16 and 17 & $-0.006^{*}$ & $-0.018^{* * *}$ & -0.003 & -0.0004 \\
\hline$[\mathrm{N}=118,994]$ & $(0.004)$ & $(0.004)$ & $(0.004)$ & $(0.001)$ \\
\hline Age 18 & $-0.034^{* *}$ & $-0.007^{* * *}$ & 0.001 & 0.003 \\
\hline$[\mathrm{N}=30,750]$ & $(0.020)$ & $(0.003)$ & $(0.007)$ & $(0.003)$ \\
\hline \multicolumn{5}{|c|}{ Panel II: Controlling for State-Specific Linear Trends } \\
\hline All Ages & -0.001 & $-0.022^{* * *}$ & -0.001 & -0.004 \\
\hline$[\mathrm{N}=235,549]$ & $(0.004)$ & $(0.005)$ & $(0.003)$ & $(0.003)$ \\
\hline Ages 14 and 15 & -0.006 & $-0.017^{* * *}$ & -0.003 & -0.005 \\
\hline$[\mathrm{N}=85,805]$ & $(0.005)$ & $(0.004)$ & $(0.005)$ & $(0.004)$ \\
\hline Ages 16 and 17 & -0.003 & $-0.027^{* * *}$ & -0.001 & -0.005 \\
\hline$[\mathrm{N}=118,994]$ & $(0.006)$ & $(0.007)$ & $(0.003)$ & $(0.004)$ \\
\hline Age 18 & $-0.042^{* * *}$ & $-0.010^{* *}$ & 0.001 & 0.006 \\
\hline$[\mathrm{N}=30,750]$ & $(0.013)$ & $(0.005)$ & $(0.010)$ & $(0.006)$ \\
\hline
\end{tabular}

*Statistically significant at the 0.10 level; ${ }^{* *}$ statistically significant at the 0.05 level;

***statistically significant at the 0.01 level.

Notes: Based on unweighted state YRBS data for the period 1995-2009. Estimated marginal probabilities

are presented. Controls include state fixed effects, year fixed effects, race, sex, age, grade, ImpacTeen cleanair laws, and the state unemployment rate. Standard errors corrected for clustering at the state level are in parentheses. The baseline category is composed of respondents who did not smoke in the past 30 days. 
Table 6. Multinomial Logit Estimates of the Effect of a $\$ 1$ Increase in the Per-Pack Cigarette Tax on How Youths Obtain Cigarettes: Stealing as a Separate Category

\begin{tabular}{lccccc}
\hline & Direct Purchase & $\begin{array}{c}\text { Third-Party } \\
\text { Purchase }\end{array}$ & $\begin{array}{c}\text { Bumming or } \\
\text { Borrowing }\end{array}$ & Stealing & $\begin{array}{c}\text { Vending Machine/ } \\
\text { Other Source }\end{array}$ \\
\hline All Ages & -0.005 & $-0.012^{* * *}$ & $-0.005^{*}$ & $-0.0013^{*}$ & -0.001 \\
[235,549] & $(0.004)$ & $(0.003)$ & $(0.003)$ & $(0.00074)$ & $(0.001)$ \\
Age 14 to 15 & -0.002 & $-0.007^{*}$ & $-0.010^{* *}$ & -0.002 & -0.003 \\
[85,805] & $(0.002)$ & $(0.004)$ & $(0.004)$ & $(0.002)$ & $(0.004)$ \\
Age 16 to 17 & -0.006 & $-0.018^{* * *}$ & -0.003 & 0.000 & -0.0004 \\
[118,994] & $(0.004)$ & $(0.004)$ & $(0.004)$ & $(0.001)$ & $(0.001)$ \\
Age 18 & $-0.034^{*}$ & $-0.007^{* * *}$ & 0.001 & -0.001 & $0.004^{*}$ \\
[30,750] & $(0.019)$ & $(0.003)$ & $(0.007)$ & $(0.002)$ & $(0.002)$ \\
\hline
\end{tabular}

*Statistically significant at the 0.10 level; ${ }^{* *}$ statistically significant at the 0.05 level;

*** statistically significant at the 0.01 level.

Notes: Based on unweighted state YRBS data for the period 1995-2009. Estimated marginal probabilities are presented. Controls include state fixed effects, year fixed effects, race, sex, age, grade, ImpacTeen clean-air laws, and the state unemployment rate. The baseline category is composed of respondents who did not smoke in the past 30 days. 
Table 7. Multinomial Logit Estimates of the Effect of a $\$ 1$ Increase in the Per-Pack Cigarette Tax on How Youths Obtain Cigarettes: "Some Other Way" as a Separate Category

\begin{tabular}{lccccc}
\hline \hline & & & & \\
& $\begin{array}{c}\text { Direct } \\
\text { Purchase }\end{array}$ & $\begin{array}{c}\text { Third-Party } \\
\text { Purchase }\end{array}$ & $\begin{array}{c}\text { Bumming or } \\
\text { Borrowing }\end{array}$ & $\begin{array}{c}\text { Some } \\
\text { Other Way }\end{array}$ & $\begin{array}{c}\text { Stealing/ } \\
\text { Vending Machine }\end{array}$ \\
\hline All Ages & -0.005 & $-0.012^{* * *}$ & $-0.005^{*}$ & -0.001 & -0.001 \\
{$[235,549]$} & $(0.004)$ & $(0.003)$ & $(0.003)$ & $(0.001)$ & $(0.001)$ \\
Age 14 to 15 & -0.002 & $-0.007^{*}$ & $-0.010^{* *}$ & -0.003 & -0.002 \\
[85,805] & $(0.002)$ & $(0.004)$ & $(0.004)$ & $(0.003)$ & $(0.002)$ \\
Age 16 to 17 & $-0.006^{*}$ & $-0.018^{* * *}$ & -0.003 & -0.001 & 0.001 \\
{$[118,994]$} & $(0.004)$ & $(0.004)$ & $(0.004)$ & $(0.002)$ & $(0.001)$ \\
Age 18 & $-0.034^{*}$ & $-0.007^{* * *}$ & 0.001 & $0.005^{* * *}$ & -0.002 \\
{$[30,750]$} & $(0.020)$ & $(0.003)$ & $(0.007)$ & $(0.002)$ & $(0.002)$ \\
\hline
\end{tabular}

*Statistically significant at the 0.10 level; ${ }^{* *}$ statistically significant at the 0.05 level;

*** statistically significant at the 0.01 level.

Notes: Based on unweighted state YRBS data for the period 1995-2009. Estimated marginal probabilities are presented. Controls include state fixed effects, year fixed effects, race, sex, age, grade, ImpacTeen clean-air laws, and the state unemployment rate. The baseline category is composed of respondents who did not smoke in the past 30 days. 
Table 8. Multinomial Logit Estimates of the Effect of a $\$ 1$ Increase in the Per-Pack Cigarette Tax on How Youths Obtain Cigarettes: Sample Limited to Respondents who Smoked at Least Once in Their Lives

\begin{tabular}{lcccc}
\hline \hline & Direct Purchase & $\begin{array}{c}\text { Third-Party } \\
\text { Purchase }\end{array}$ & $\begin{array}{c}\text { Bumming or } \\
\text { Borrowing }\end{array}$ & $\begin{array}{c}\text { Vending Machine, } \\
\text { Stealing or Other }\end{array}$ \\
\hline All Ages & -0.006 & $-0.018^{* * *}$ & -0.002 & -0.001 \\
{$[\mathrm{~N}=129,134]$} & $(0.005)$ & $(0.004)$ & $(0.004)$ & $(0.004)$ \\
Ages 14 and 15 & -0.002 & -0.010 & -0.013 & -0.007 \\
{$[\mathrm{~N}=41,025]$} & $(0.004)$ & $(0.007)$ & $(0.008)$ & $(0.010)$ \\
Ages 16 and 17 & -0.007 & $-0.025^{* * *}$ & 0.004 & 0.002 \\
{$[\mathrm{~N}=68,637]$} & $(0.005)$ & $(0.005)$ & $(0.006)$ & $(0.003)$ \\
Age 18 & -0.038 & $-0.012^{* * *}$ & 0.008 & $0.008^{*}$ \\
{$[\mathrm{~N}=19,472]$} & $(0.026)$ & $(0.003)$ & $(0.010)$ & $(0.004)$ \\
\hline
\end{tabular}

*Statistically significant at the 0.10 level; ${ }^{* *}$ statistically significant at the 0.05 level;

***statistically significant at the 0.01 level.

Notes: Based on unweighted state YRBS data for the period 1995-2009. Estimated marginal probabilities are presented. Controls include state fixed effects, year fixed effects, race, sex, age, grade, ImpacTeen cleanair laws, and the state unemployment rate. Standard errors corrected for clustering at the state level are in parentheses. The baseline category is composed of respondents who did not smoke in the past 30 days. 
Table 9. Multinomial Logit Estimates of the Effect of a $\$ 1$ Increase in the Per-Pack Cigarette Tax on How Youths Obtain Cigarettes: Sample Limited to Frequent Smokers

\begin{tabular}{lccc}
\hline \hline & & & \\
\hline & $\begin{array}{c}\text { Third-Party } \\
\text { Purchase }\end{array}$ & $\begin{array}{c}\text { Bumming or } \\
\text { Borrowing }\end{array}$ & $\begin{array}{c}\text { Vending Machine, } \\
\text { Stealing or Other }\end{array}$ \\
\hline All Ages & -0.019 & -0.001 & 0.009 \\
{$[\mathrm{~N}=27,596]$} & $(0.013)$ & $(0.006)$ & $(0.011)$ \\
Ages 14 and 15 & -0.008 & 0.004 & -0.002 \\
{$[\mathrm{~N}=6,570]$} & $(0.033)$ & $(0.012)$ & $(0.033)$ \\
Ages 16 and 17 & $-0.035^{* * *}$ & -0.003 & 0.015 \\
{$[\mathrm{~N}=15,580]$} & $(0.013)$ & $(0.012)$ & $(0.010)$ \\
Age 18 & $-0.018^{* *}$ & 0.008 & 0.012 \\
{$[\mathrm{~N}=5,446]$} & $(0.008)$ & $(0.012)$ & $(0.007)$ \\
\hline
\end{tabular}

*Statistically significant at the 0.10 level; ${ }^{* *}$ statistically significant at the 0.05 level;

*** statistically significant at the 0.01 level.

Notes: Based on unweighted state YRBS data for the period 1995-2009. Estimated marginal probabilities are presented. Controls include state fixed effects, year fixed effects, race, sex, age, grade, ImpacTeen clean-air laws, and the state unemployment rate. Standard errors corrected for clustering at the state level are in parentheses. The baseline category is composed of respondents who usually directly purchased their cigarettes directly from a commercial establishment. 
Table 10. Multinomial Logit Estimates of the Effect of a $\$ 1$ Increase in the Per-Pack Cigarette Tax on How Youths Obtain Cigarettes: Sample Limited to Everyday Smokers

\begin{tabular}{lccc}
\hline \hline & $\begin{array}{c}\text { Third-Party } \\
\text { Purchase }\end{array}$ & $\begin{array}{c}\text { Bumming or } \\
\text { Borrowing }\end{array}$ & $\begin{array}{c}\text { Vending Machine, } \\
\text { Stealing or Other }\end{array}$ \\
\hline All Ages & $-0.036^{* * *}$ & 0.008 & 0.010 \\
{$[\mathrm{~N}=27,596]$} & $(0.014)$ & $(0.007)$ & $(0.012)$ \\
Ages 14 and 15 & -0.026 & 0.025 & 0.007 \\
{$[\mathrm{~N}=6,570]$} & $(0.040)$ & $(0.015)$ & $(0.052)$ \\
Ages 16 and 17 & $-0.046^{* *}$ & 0.000 & 0.011 \\
{$[\mathrm{~N}=15,580]$} & $(0.015)$ & $(0.011)$ & $(0.012)$ \\
Age 18 & $-0.039^{* * *}$ & $0.017^{*}$ & $0.019^{* * *}$ \\
{$[\mathrm{~N}=5,446]$} & $(0.010)$ & $(0.010)$ & $(0.008)$ \\
\hline
\end{tabular}

*Statistically significant at the 0.10 level; ${ }^{* *}$ statistically significant at the 0.05 level;

*** statistically significant at the 0.01 level.

Notes: Based on unweighted state YRBS data for the period 1995-2009. Estimated marginal probabilities are presented. Controls include state fixed effects, year fixed effects, race, sex, age, grade, ImpacTeen clean-air laws, and the state unemployment rate. Standard errors corrected for clustering at the state level are in parentheses. The baseline category is composed of respondents who usually directly purchased their cigarettes directly from a commercial establishment. 
Appendix Table 1A. Mean Number of Friends who Smoked by Age and Smoking Behavior of the Add Health Respondent

\begin{tabular}{lcccc}
\hline \hline & $\begin{array}{c}\text { All Add Health } \\
\text { Respondents }\end{array}$ & Smokers & $\begin{array}{c}\text { Frequent } \\
\text { Smokers }\end{array}$ & $\begin{array}{c}\text { Everyday } \\
\text { Smokers }\end{array}$ \\
\hline Ages 14 and 15 & 0.79 & 1.68 & 2.22 & 2.30 \\
& $(1.05)$ & $(1.13)$ & $(0.96)$ & $(0.94)$ \\
Ages $\mathbf{1 6}$ and $\mathbf{1 7}$ & {$[5,662]$} & {$[1,352]$} & {$[557]$} & {$[376]$} \\
& 1.00 & 1.78 & 2.18 & 2.26 \\
& $(1.12)$ & $(1.09)$ & $(0.92)$ & $(0.87)$ \\
Age 18 & {$[7,226]$} & {$[2,141]$} & {$[1,112]$} & {$[804]$} \\
& 1.12 & 1.84 & 2.15 & 2.21 \\
& $(1.14)$ & $(1.11)$ & $(1.01)$ & {$[0.99)$} \\
\hline
\end{tabular}

Notes: Based on weighted data from Wave I of the National Longitudinal Study of Adolescent Health, collected in 1995. Number of friends who smoked is constructed from answers to the question, "[o]f your 3 best friends, how many smoke at least 1 cigarette a day?" Standard deviations are in parentheses and sample sizes are in brackets. 
Appendix Table 1B. Mean Number of Friends who Smoked by Age and Years since Add Health Respondent had First Cigarette

\begin{tabular}{lcccc}
\hline \hline & & & & \\
& 1st Cigarette & 1st Cigarette & 1st Cigarette & 1st Cigarette \\
within 1 Year & 1-2 Years Ago & 3-4 Years Ago & 5+ Years Ago \\
\hline Ages 14 and 15 & 0.96 & 1.20 & 1.41 & 1.64 \\
& $(1.04)$ & $(1.18)$ & $(1.19)$ & $(1.20)$ \\
Ages $\mathbf{1 6}$ and $\mathbf{1 7}$ & {$[321]$} & {$[1,175]$} & {$[461]$} & {$[323]$} \\
& 1.09 & 1.24 & 1.58 & 1.65 \\
& $(1.03)$ & $(1.12)$ & $(1.13)$ & $(1.18)$ \\
Age $\mathbf{1 8}$ & {$[277]$} & {$[1,285]$} & {$[1,001]$} & {$[886]$} \\
& 1.21 & 1.47 & 1.58 & 1.68 \\
& $(1.07)$ & $(1.16)$ & $(1.17)$ & $(1.15)$ \\
& {$[73]$} & {$[436]$} & {$[356]$} & {$[495]$} \\
\hline
\end{tabular}

Notes: Based on weighted data from Wave I of the National Longitudinal Study of Adolescent Health, collected in 1995. Number of friends who smoked is constructed from answers to the question, "[o]f your 3 best friends, how many smoke at least 1 cigarette a day?" Standard deviations are in parentheses and sample sizes are in brackets. 
Appendix Table 2. Number of Observations by State-Year

\begin{tabular}{lccccccccc}
\hline \hline & 1995 & 1997 & 1999 & 2001 & 2003 & 2005 & 2007 & 2009 & Total \\
\hline AK & 1,549 & - & - & - & 1,376 & - & 1,201 & 1,150 & 5,276 \\
AR & 2,153 & 1,868 & 1,389 & 1,603 & - & 1,397 & 1,456 & 1,456 & 11,355 \\
AZ & - & - & - & - & 1,858 & 1,773 & 1,542 & 1,374 & 5,547 \\
CO & - & - & - & - & - & 1,404 & - & 1,385 & 2,789 \\
DE & - & - & 2,235 & 2,724 & 2,805 & 2,486 & 2,218 & 2,113 & 14,581 \\
IA & - & 1,457 & - & - & - & 1,319 & 1,380 & - & 4,156 \\
ID & - & - & - & 1,590 & 1,616 & 1,351 & 1,306 & 2,015 & 7,878 \\
IL & 2,868 & - & - & - & - & - & 2,221 & 2,696 & 7,785 \\
KS & - & - & - & - & - & 1,563 & 1,609 & 1,919 & 5,091 \\
KY & - & 1,516 & - & - & 1,476 & 3,026 & 3,202 & 1,615 & 10,835 \\
MD & - & - & - & - & - & 1,331 & 1,375 & 1,479 & 4,185 \\
ME & 1,335 & 1,752 & - & 1,235 & 1,540 & 1,540 & - & 7,770 & 14,878 \\
MO & 4,618 & 1,390 & 1,575 & 1,574 & 1,485 & 1,803 & 1,452 & 1,531 & 15,428 \\
MS & 1,209 & 1,396 & 1,525 & 1,676 & 1,403 & - & 1,445 & 1,681 & 10,335 \\
MT & 2,385 & 2,427 & 2,776 & 2,401 & 2,489 & 2,804 & 3,668 & 1,700 & 20,650 \\
ND & - & - & 1,713 & 1,485 & 1,555 & 1,622 & 1,627 & 1,716 & 9,718 \\
NE & - & - & - & - & 2,608 & 3,484 & - & - & 6,092 \\
NY & - & 3,522 & 3,236 & - & 8,566 & 8,879 & - & - & 24,203 \\
SC & - & - & 4,234 & - & - & 1,189 & 1,114 & 1,001 & 7,538 \\
SD & 1,128 & 1,513 & 1,587 & 1,435 & 1,666 & 1,470 & 1,469 & 1,998 & 12,266 \\
TN & - & - & - & - & 1,835 & 1,462 & 1,939 & 2,105 & 7,341 \\
UT & 3,085 & 1,327 & 1,434 & 1,009 & 1,330 & 1,408 & 1,803 & 1,493 & 12,888 \\
WI & - & 1,247 & 1,267 & 1,982 & 1,985 & 2,249 & 1,978 & - & 10,708 \\
WV & 1,992 & 1,738 & 1,372 & - & 1,642 & 1,279 & 1,290 & 1,483 & 10,796 \\
\hline
\end{tabular}

Note: In order to be included in our analysis, states must have conducted a YRBS, given the CDC permission to distribute the results, asked questions with regard to how respondents usually obtained their cigarettes, and provided at least two years of data to the CDC. 
Appendix Table 3. Per-Pack Cigarette Tax for States Contributing YRBS Data, 1995-2009 (in cents)

\begin{tabular}{lcccccccc}
\hline \hline & 1995 & 1997 & 1999 & 2001 & 2003 & 2005 & 2007 & 2009 \\
\hline AK & 29 & 29 & 100 & 100 & 100 & 160 & 180 & 200 \\
AR & 31.5 & 31.5 & 31.5 & 31.5 & 59 & 59 & 59 & 115 \\
AZ & 18 & 58 & 58 & 58 & 118 & 118 & 200 & 200 \\
CO & 20 & 20 & 20 & 20 & 20 & 84 & 84 & 84 \\
DE & 24 & 24 & 24 & 24 & 24 & 55 & 55 & 115 \\
IA & 36 & 36 & 36 & 36 & 36 & 36 & 136 & 136 \\
ID & 18 & 28 & 28 & 28 & 57 & 57 & 57 & 57 \\
IL & 44 & 44 & 58 & 58 & 98 & 98 & 98 & 98 \\
KS & 24 & 24 & 24 & 79 & 79 & 79 & 79 & 79 \\
KY & 3 & 3 & 3 & 3 & 3 & 30 & 30 & 60 \\
MD & 36 & 36 & 66 & 100 & 100 & 100 & 100 & 200 \\
ME & 37 & 37 & 74 & 74 & 100 & 100 & 200 & 200 \\
MO & 17 & 17 & 17 & 17 & 17 & 17 & 17 & 17 \\
MS & 18 & 18 & 18 & 18 & 18 & 18 & 18 & 68 \\
MT & 18 & 18 & 18 & 18 & 70 & 170 & 170 & 170 \\
ND & 44 & 44 & 44 & 44 & 44 & 44 & 44 & 44 \\
NE & 34 & 34 & 34 & 34 & 64 & 64 & 64 & 64 \\
NY & 56 & 56 & 56 & 111 & 150 & 150 & 150 & 275 \\
SC & 7 & 7 & 7 & 7 & 7 & 7 & 7 & 7 \\
SD & 23 & 33 & 33 & 33 & 53 & 53 & 153 & 153 \\
TN & 13 & 13 & 13 & 13 & 20 & 20 & 20 & 62 \\
UT & 26.5 & 26.5 & 51.5 & 51.5 & 69.5 & 69.5 & 69.5 & 69.5 \\
WI & 38 & 44 & 59 & 59 & 77 & 77 & 77 & 252 \\
WV & 17 & 17 & 17 & 17 & 55 & 55 & 55 & 55 \\
\hline Note: Per-pack state cigarette tax obtained from Orzechowski and \\
Walker $(2009)$. & & & & & & & \\
& & & & & & & &
\end{tabular}


Appendix Table 4. Descriptive Statistics for Selected Independent Variables by Age

\begin{tabular}{lcccc}
\multicolumn{5}{c}{ (standard deviations in parentheses) } \\
\hline \hline & Full Sample & 14 and15 & 16 and17 & 18 \\
\hline Cigarette Tax (2005 dollars) & 0.693 & 0.716 & 0.686 & 0.657 \\
& $(0.507)$ & $(0.515)$ & $(0.502)$ & $(0.496)$ \\
Male & 0.495 & 0.462 & 0.487 & 0.374 \\
& $(0.499)$ & $(0.498)$ & $(0.499)$ & $(0.497)$ \\
Black & 0.127 & 0.124 & 0.127 & 0.139 \\
& $(0.334)$ & $(0.329)$ & $(0.333)$ & $(0.346)$ \\
Hispanic & 0.086 & 0.092 & 0.083 & 0.082 \\
& $(0.281)$ & $(0.289)$ & $(0.276)$ & $(0.274)$ \\
Grade 9 & 0.289 & 0.728 & 0.046 & 0.005 \\
& $(0.453)$ & $(0.444)$ & $(0.209)$ & $(0.073)$ \\
Grade 10 & 0.271 & 0.264 & 0.343 & 0.011 \\
& $(0.444)$ & $(0.441)$ & $(0.475)$ & $(0.103)$ \\
Grade 11 & 0.244 & 0.003 & 0.455 & 0.103 \\
& $(0.429)$ & $(0.050)$ & $(0.498)$ & $(0.304)$ \\
Unemployment Rate & 0.062 & 0.063 & $(0.062)$ & 0.061 \\
& $(0.019)$ & $(0.019)$ & $(0.019)$ & $(0.020)$ \\
\hline Observations & 235,549 & 85,805 & 118,994 & 30,750 \\
\hline
\end{tabular}

Note: Based on unweighted state YRBS data for the period 1995-2009. 


\section{Appendix Table 5. Logit Estimates of the Determinants of Smoking Participation}

\begin{tabular}{|c|c|c|c|c|}
\hline & All Ages & 14 and 15 & 16 and 17 & 18 \\
\hline Male & $\begin{array}{c}-0.004 \\
(0.004)\end{array}$ & $\begin{array}{c}-0.023^{* * *} \\
(0.004)\end{array}$ & $\begin{array}{c}-0.002 \\
(0.005)\end{array}$ & $\begin{array}{l}0.036^{* * *} \\
(0.007)\end{array}$ \\
\hline Black & $\begin{array}{c}-0.188^{* * *} \\
(0.024)\end{array}$ & $\begin{array}{l}-0.160^{* * *} \\
(0.024)\end{array}$ & $\begin{array}{l}-0.198^{* *} \\
(0.024)\end{array}$ & $\begin{array}{c}-0.220^{* * *} \\
(0.027)\end{array}$ \\
\hline Hispanic & $\begin{array}{c}-0.046^{* * *} \\
(0.015)\end{array}$ & $\begin{array}{l}-0.023 \\
(0.016)\end{array}$ & $\begin{array}{c}-0.0566^{* * *} \\
(0.014)\end{array}$ & $\begin{array}{c}-0.0796^{* * *} \\
(0.022)\end{array}$ \\
\hline Grade 9 & $\begin{array}{l}0.048^{* * *} \\
(0.013)\end{array}$ & $\begin{array}{c}-0.113^{* * *} \\
(0.023)\end{array}$ & $\begin{array}{c}0.105^{* * *} \\
(0.013)\end{array}$ & $\begin{array}{c}0.295^{* * *} \\
(0.004)\end{array}$ \\
\hline Grade 10 & $\begin{array}{l}0.024^{* * *} \\
(0.008)\end{array}$ & $\begin{array}{c}-0.111^{* * *} \\
(0.024)\end{array}$ & $\begin{array}{c}0.008 \\
(0.008)\end{array}$ & $\begin{array}{l}0.148^{* * *} \\
(0.026)\end{array}$ \\
\hline Grade 11 & $\begin{array}{c}0.003 \\
(0.004)\end{array}$ & $\begin{array}{l}0.109^{* * *} \\
(0.032)\end{array}$ & $\begin{array}{l}-0.006 \\
(0.004)\end{array}$ & $\begin{array}{l}0.036^{* * *} \\
(0.009)\end{array}$ \\
\hline Age 15 & $\begin{array}{l}0.053^{* * *} \\
(0.005)\end{array}$ & $\begin{array}{l}0.042^{* * *} \\
(0.004)\end{array}$ & & \\
\hline Age 16 & $\begin{array}{l}0.113^{* * *} \\
(0.009)\end{array}$ & & & \\
\hline Age 17 & $\begin{array}{l}0.159^{* * *} \\
(0.012)\end{array}$ & & $\begin{array}{l}0.045^{* * *} \\
(0.005)\end{array}$ & \\
\hline Age 18 & $\begin{array}{l}0.193^{* * *} \\
(0.014)\end{array}$ & & & \\
\hline Unemp. Rate & $\begin{array}{l}0.417^{* * *} \\
(0.129)\end{array}$ & $\begin{array}{l}0.756^{* * *} \\
(0.148)\end{array}$ & $\begin{array}{c}0.240 \\
(0.173)\end{array}$ & $\begin{array}{c}0.095 \\
(0.372)\end{array}$ \\
\hline Observations & 235,549 & 85,805 & 118,994 & 30,750 \\
\hline
\end{tabular}

*Statistically significant at the 0.10 level; ${ }^{* *}$ statistically significant at the 0.05 level;

***Statistically significant at the 0.01 level.

Notes: Based on unweighted state YRBS data for the period 1995-2009. Estimated marginal probabilities are presented. Additional variables include the state per-pack cigarette tax, state fixed effects, year fixed effects, and ImpacTeen clean-air laws. Standard errors corrected for clustering at the state level are in parentheses. 
Appendix Table 6A. Method of Obtaining Cigarettes by Age: Sample Restricted to State YRBS Respondents Who Smoked at Least Once

\begin{tabular}{|c|c|c|c|c|}
\hline & Direct Purchase & $\begin{array}{l}\text { Third-Party } \\
\text { Purchase }\end{array}$ & $\begin{array}{l}\text { Buming or } \\
\text { Borrowing }\end{array}$ & $\begin{array}{l}\text { Vending Machine, } \\
\text { Stealing or Other }\end{array}$ \\
\hline $\begin{array}{l}\text { All Ages } \\
{[\mathrm{N}=123,997]}\end{array}$ & 0.126 & 0.116 & 0.137 & 0.064 \\
\hline $\begin{array}{l}\text { Ages } 14 \text { and } \mathbf{1 5} \\
{[\mathrm{N}=39,363]}\end{array}$ & 0.046 & 0.126 & 0.154 & 0.084 \\
\hline $\begin{array}{l}\text { Ages } 16 \text { and } 17 \\
{[\mathrm{~N}=66,059]}\end{array}$ & 0.104 & 0.139 & 0.144 & 0.062 \\
\hline $\begin{array}{l}\text { Age } 18 \\
{[\mathrm{~N}=18,575]}\end{array}$ & 0.374 & 0.020 & 0.076 & 0.027 \\
\hline
\end{tabular}


Appendix Table 6B. Method of Obtaining Cigarettes by Age: Sample Restricted to State YRBS Respondents Who Smoked Frequently

\begin{tabular}{|c|c|c|c|c|}
\hline & Direct Purchase & $\begin{array}{c}\text { Third-Party } \\
\text { Purchase }\end{array}$ & $\begin{array}{l}\text { Buming or } \\
\text { Borrowing }\end{array}$ & $\begin{array}{l}\text { Vending Machine, } \\
\text { Stealing or Other }\end{array}$ \\
\hline $\begin{array}{l}\text { All Ages } \\
{[\mathrm{N}=235,549]}\end{array}$ & 0.392 & 0.369 & 0.100 & 0.138 \\
\hline $\begin{array}{l}\text { Ages } 14 \text { and } 15 \\
{[\mathrm{~N}=85,805]}\end{array}$ & 0.174 & 0.490 & 0.141 & 0.195 \\
\hline $\begin{array}{l}\text { Ages } \mathbf{1 6} \text { and } \mathbf{1 7} \\
{[\mathrm{N}=118,994]}\end{array}$ & 0.317 & 0.431 & 0.108 & 0.143 \\
\hline $\begin{array}{l}\text { Age } \mathbf{1 8} \\
{[\mathrm{N}=30,750]}\end{array}$ & 0.870 & 0.046 & 0.029 & 0.055 \\
\hline
\end{tabular}


Appendix Table 6C. Method of Obtaining Cigarettes by Age: Sample Restricted to State YRBS Respondents Who Smoked Everyday

\begin{tabular}{|c|c|c|c|c|}
\hline & Direct Purchase & $\begin{array}{c}\text { Third-Party } \\
\text { Purchase }\end{array}$ & $\begin{array}{l}\text { Buming or } \\
\text { Borrowing }\end{array}$ & $\begin{array}{l}\text { Vending Machine, } \\
\text { Stealing or Other }\end{array}$ \\
\hline $\begin{array}{l}\text { All Ages } \\
{[\mathrm{N}=235,549]}\end{array}$ & 0.414 & 0.357 & 0.082 & 0.146 \\
\hline $\begin{array}{l}\text { Ages } 14 \text { and } 15 \\
{[\mathrm{~N}=85,805]}\end{array}$ & 0.195 & 0.480 & 0.118 & 0.206 \\
\hline $\begin{array}{l}\text { Ages } \mathbf{1 6} \text { and } \mathbf{1 7} \\
{[\mathrm{N}=118,994]}\end{array}$ & 0.332 & 0.423 & 0.090 & 0.154 \\
\hline $\begin{array}{l}\text { Age 18 } \\
{[\mathrm{N}=30,750]}\end{array}$ & 0.872 & 0.043 & 0.024 & 0.061 \\
\hline
\end{tabular}




\section{Appendix Table 7. Multinomial Logit Estimates of the Effect of a $\$ 1$ Increase in the Per-Pack Cigarette Tax on How Youths Obtain Cigarettes: Sample Restricted to Frequent Smokers and Stealing as a Separate Category}

\begin{tabular}{|c|c|c|c|c|}
\hline & $\begin{array}{l}\text { Third-Party } \\
\text { Purchase }\end{array}$ & $\begin{array}{l}\text { Bumming or } \\
\text { Borrowing }\end{array}$ & Stealing & $\begin{array}{c}\text { Vending Machine } \\
\text { or Other }\end{array}$ \\
\hline All Ages & -0.019 & -0.001 & 0.004 & 0.006 \\
\hline$[27,596]$ & $(0.013)$ & $(0.006)$ & $(0.004)$ & $(0.009)$ \\
\hline Age 14 to 15 & 0.008 & 0.004 & -0.000 & -0.003 \\
\hline$[6,570]$ & $(0.033)$ & $(0.012)$ & $(0.006)$ & $(0.030)$ \\
\hline Age 16 to 17 & $-0.035^{* * *}$ & -0.003 & 0.006 & 0.010 \\
\hline$[15,580]$ & $(0.013)$ & $(0.012)$ & $(0.005)$ & $(0.009)$ \\
\hline Age 18 & $-0.018^{* *}$ & 0.008 & 0.004 & $0.009^{* *}$ \\
\hline$[5,446]$ & $(0.008)$ & $(0.012)$ & $(0.007)$ & $(0.004)$ \\
\hline
\end{tabular}

*Statistically significant at the 0.10 level; ${ }^{* *}$ statistically significant at the 0.05 level;

***statistically significant at the 0.01 level.

Notes: Based on unweighted state YRBS data for the period 1995-2009. Estimated marginal probabilities are presented. Controls include state fixed effects, year fixed effects, race, sex, age, grade, ImpacTeen cleanair laws, and the state unemployment rate. Standard errors corrected for clustering at the state level are in parentheses. The baseline category is composed of respondents who purchased their cigarettes directly from a commercial establishment. 


\section{Appendix Table 8. Multinomial Logit Estimates of the Effect of a $\$ 1$ Increase in the Per-Pack Cigarette Tax on How Youths Obtain Cigarettes: Sample Restricted to Everyday Smokers and Stealing as a Separate Category}

\begin{tabular}{lcccc}
\hline & $\begin{array}{c}\text { Third-Party } \\
\text { Purchase }\end{array}$ & $\begin{array}{c}\text { Bumming or } \\
\text { Borrowing }\end{array}$ & Stealing & $\begin{array}{c}\text { Vending Machine } \\
\text { or Other }\end{array}$ \\
\hline All Ages & $-0.037^{* * *}$ & 0.007 & 0.005 & 0.007 \\
{$[20,790]$} & $(0.014)$ & $(0.007)$ & $(0.005)$ & $(0.009)$ \\
Age 14 to 15 & -0.025 & $0.025^{*}$ & -0.008 & 0.013 \\
{$[4,658]$} & $(0.040)$ & $(0.015)$ & $(0.016)$ & $(0.041)$ \\
Age 16 to 17 & $-0.046^{* * *}$ & -0.000 & 0.008 & 0.005 \\
{$[11,794]$} & $(0.015)$ & $(0.011)$ & $(0.005)$ & $(0.013)$ \\
Age 18 & $-0.039^{* * *}$ & $0.017^{*}$ & 0.007 & $0.014^{* * *}$ \\
{$[4,338]$} & $(.010)$ & $(0.010)$ & $(0.008)$ & $(0.005)$ \\
\hline
\end{tabular}

*Statistically significant at the 0.10 level; ${ }^{* *}$ statistically significant at the 0.05 level;

***statistically significant at the 0.01 level.

Notes: Based on unweighted state YRBS data for the period 1995-2009. Estimated marginal probabilities are presented. Controls include state fixed effects, year fixed effects, race, sex, age, grade, ImpacTeen cleanair laws, and the state unemployment rate. Standard errors corrected for clustering at the state level are in parentheses. The baseline category is composed of respondents who purchased their cigarettes directly from a commercial establishment. 
Appendix Table 9. Multinomial Logit Estimates of the Effect of a $\$ 1$ Increase in the Per-Pack Cigarette Tax on How Youths Obtain Cigarettes: Sample Restricted to Frequent Smokers and "Some Other Way" as a Separate Category

\begin{tabular}{lcccc}
\hline \hline & $\begin{array}{c}\text { Third-Party } \\
\text { Purchase }\end{array}$ & $\begin{array}{c}\text { Bumming or } \\
\text { Borrowing }\end{array}$ & $\begin{array}{c}\text { Some Other } \\
\text { Way }\end{array}$ & $\begin{array}{c}\text { Stealing or } \\
\text { Vending Machine }\end{array}$ \\
\hline All Ages & -0.019 & -0.001 & 0.003 & 0.007 \\
{$[27,596]$} & $(0.013)$ & $(0.006)$ & $(0.007)$ & $(0.006)$ \\
Age 14 to 15 & -0.010 & 0.009 & 0.004 & -0.010 \\
{$[6,570]$} & $(0.013)$ & $(0.032)$ & $(0.012)$ & $(0.028)$ \\
Age 16 to 17 & $-0.035^{* * *}$ & -0.003 & 0.006 & 0.010 \\
{$[15,580]$} & $(0.013)$ & $(0.012)$ & $(0.009)$ & $(0.007)$ \\
Age 18 & $-0.018^{* *}$ & 0.007 & $0.013^{* * *}$ & -0.0003 \\
{$[5,446]$} & $(0.008)$ & $(0.012)$ & $(0.004)$ & $(0.006)$ \\
\hline
\end{tabular}

*Statistically significant at the 0.10 level; ${ }^{* *}$ statistically significant at the 0.05 level;

***statistically significant at the 0.01 level.

Notes: Based on unweighted state YRBS data for the period 1995-2009. Estimated marginal probabilities

are presented. Controls include state fixed effects, year fixed effects, race, sex, age, grade, ImpacTeen cleanair laws, and the state unemployment rate. Standard errors corrected for clustering at the state level are in parentheses. The baseline category is composed of respondents who purchased their cigarettes directly from a commercial establishment. 


\section{Appendix Table 10. Multinomial Logit Estimates of the Effect of a $\$ 1$ Increase in the Per-Pack Cigarette Tax on How Youths Obtain Cigarettes: Sample Restricted to Everyday Smokers and "Some Other Way" as Separate Category}

\begin{tabular}{lcccc}
\hline & $\begin{array}{c}\text { Third-Party } \\
\text { Purchase }\end{array}$ & $\begin{array}{c}\text { Bumming or } \\
\text { Borrowing }\end{array}$ & $\begin{array}{c}\text { Some Other } \\
\text { Way }\end{array}$ & $\begin{array}{c}\text { Stealing or } \\
\text { Vending Machine }\end{array}$ \\
\hline All Ages & $-0.036^{* * *}$ & 0.008 & 0.003 & 0.008 \\
{$[20,790]$} & $(0.014)$ & $(0.007)$ & $(0.008)$ & $(0.006)$ \\
Age 14 to 15 & -0.025 & $0.025^{*}$ & -0.002 & 0.007 \\
{$[4,658]$} & $(0.040)$ & $(0.015)$ & $(0.040)$ & $(0.017)$ \\
Age 16 to 17 & $-0.045^{* * *}$ & 0.000 & 0.001 & 0.010 \\
{$[11,794]$} & $(0.015)$ & $(0.011)$ & $(0.013)$ & $0.006)$ \\
Age 18 & $-0.039^{* * *}$ & $0.017^{*}$ & $0.018^{* * *}$ & $(0.007)$ \\
{$[4,338]$} & $(0.010)$ & $(0.010)$ & $(0.005)$ & \\
\hline
\end{tabular}

*Statistically significant at the 0.10 level; ${ }^{* *}$ statistically significant at the 0.05 level;

***statistically significant at the 0.01 level.

Notes: Based on unweighted state YRBS data for the period 1995-2009. Estimated marginal probabilities are presented. Controls include state fixed effects, year fixed effects, race, sex, age, grade, ImpacTeen cleanair laws, and the state unemployment rate. Standard errors corrected for clustering at the state level are in parentheses. The baseline category is composed of respondents who purchased their cigarettes directly from a commercial establishment. 